\title{
Biomass burning and urban air pollution over the Central Mexican Plateau
}

\author{
J. D. Crounse ${ }^{1}$, P. F. DeCarlo ${ }^{2,}$, D. R. Blake ${ }^{3}$, L. K. Emmons ${ }^{4}$, T. L. Campos $^{4}$, E. C. Apel ${ }^{4}$, A. D. Clarke ${ }^{5}$, \\ A. J. Weinheimer ${ }^{4}$, D. C. McCabe ${ }^{7, * *}$, R. J. Yokelson ${ }^{6}$, J. L. Jimenez ${ }^{2}$, and P. O. Wennberg ${ }^{7,8}$ \\ ${ }^{1}$ Division of Chemistry and Chemical Engineering, California Institute of Technology, Pasadena, CA 91125, USA \\ ${ }^{2}$ University of Colorado, Boulder, CO, USA \\ ${ }^{3}$ Department of Chemistry, University of California at Irvine, Irvine, CA, USA \\ ${ }^{4}$ National Center for Atmospheric Research, Boulder, CO, USA \\ ${ }^{5}$ Department of Oceanography, University of Hawaii, USA \\ ${ }^{6}$ Department of Chemistry, University of Montana, Missoula, MT, USA \\ ${ }^{7}$ Division of Geological and Planetary Sciences, California Institute of Technology, Pasadena, CA, USA \\ ${ }^{8}$ Division of Engineering and Applied Science, California Institute of Technology, Pasadena, CA, USA \\ *now at: Laboratory of Atmospheric Chemistry, Paul Scherrer Institute, Switzerland \\ ** now at: AAAS Science and Technology Policy Fellow, United States Environmental Protection Agency, \\ Washington, D.C., USA
}

Received: 18 November 2008 - Published in Atmos. Chem. Phys. Discuss.: 28 January 2009

Revised: 12 May 2009 - Accepted: 9 July 2009 - Published: 24 July 2009

\begin{abstract}
Observations during the 2006 dry season of highly elevated concentrations of cyanides in the atmosphere above Mexico City (MC) and the surrounding plains demonstrate that biomass burning (BB) significantly impacted air quality in the region. We find that during the period of our measurements, fires contribute more than half of the organic aerosol mass and submicron aerosol scattering, and one third of the enhancement in benzene, reactive nitrogen, and carbon monoxide in the outflow from the plateau. The combination of biomass burning and anthropogenic emissions will affect ozone chemistry in the MC outflow.
\end{abstract}

\section{Introduction}

The 20 million (2005) inhabitants of Mexico City experience some of the worst air quality in the world. The high population density coupled with the topography of the city ( $2200 \mathrm{~m}$, surrounded on three sides by mountains) leads to the daily buildup of pollutants in the region (Molina and Molina, 2002). Despite growing population and greatly increased automobile use, air quality has improved measurably

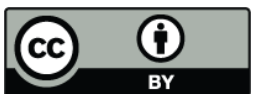

Correspondence to: J. D. Crounse (crounjd@ caltech.edu) in the last decade as the federal and city governments implemented a series of air quality regulations broadly similar to those that have been effective in, for example, Los Angeles (Lloyd, 1992). Nevertheless, ozone and particulate matter (PM) in the city often exceed international standards (WHO, 2008) and the city is consistently enveloped in a pall by the large amount of aerosol present.

The pollution from the city has impacts beyond the basin. Aerosols and ozone produce important forcing on regional climate through their interaction with both thermal infrared and visible radiation (Solomon et al., 2007). Indeed, the effluents from megacities, such as Mexico City, are now seen as globally important sources of pollution.

In the last decade, there have been several intensive studies of the air quality in the Mexico City basin. A major study undertaken in the Mexico City Metropolitan Area in spring of 2003 (MCMA-2003) included significant international cooperation (Molina et al., 2007). In the spring of 2006, a consortium of atmospheric scientists expanded significantly on this study, obtaining a large suite of measurements in and around Mexico City in an effort to understand both the controlling chemistry in the basin and the impacts of the outflow pollution on the broader region. Named Megacity Initiative: Local and Global Research Observations (MILAGRO), this campaign involved measurements at several ground sites along the most common outflow trajectory, and from several

Published by Copernicus Publications on behalf of the European Geosciences Union. 
(a)

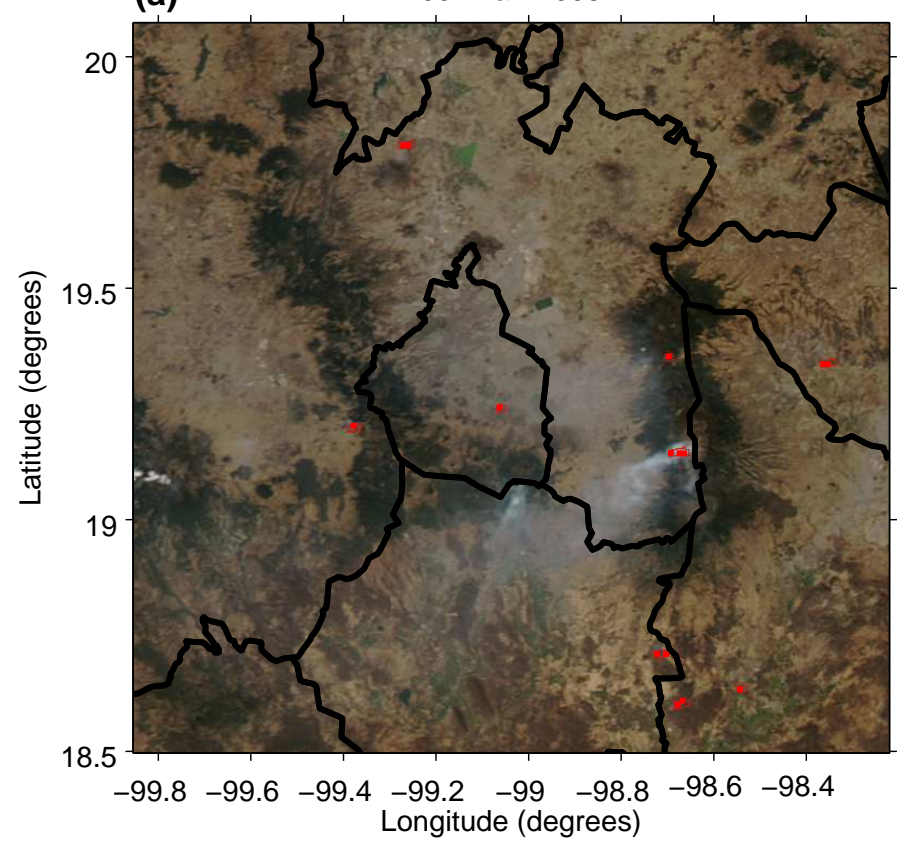

(b)

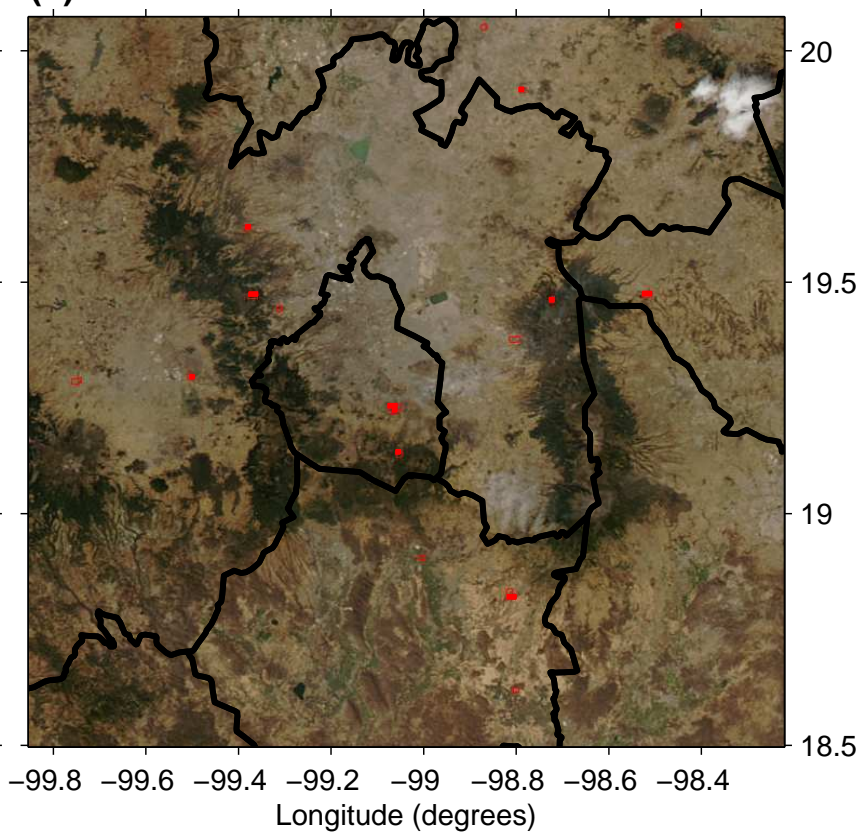

Fig. 1. MODIS-Aqua images of the Mexico City basin on (a) 5 March 2006 at 13:35 CST and (b) 10 March 2006 at 13:55 CST, illustrate how large fires in the hillsides surrounding the city can impact visibility. Red boxes are thermal anomalies detected by MODIS. Black lines represent Mexican state boundaries. Images courtesy of MODIS Rapid Response Project at NASA/GSFC.

aircraft. The National Science Foundation (NSF) C-130 (operated by the National Center for Atmospheric Research (NCAR)), and the US Forest Service Twin Otter, along with several other aircraft operated from Veracruz, Mexico. Here, we focus on observations made from the $\mathrm{C}$-130 aircraft on seven flights above the Central Mexican Plateau. Details about the broader MILAGRO study are reviewed by Fast et al. (2007).

Most efforts to engineer improvements in Mexico City air quality have logically focused on reducing emissions from the transportation and power generation sectors (McKinley et al., 2005) and on new liquefied petroleum gas (LPG) regulations. However, as in Los Angeles, as the emissions from transportation and industrial sectors decline, continued improvement in air quality will require addressing additional sources.

Biomass burning can be a significant contributor to poor air quality in many regions of the world, including southern California (Muhle et al., 2007). Several previous studies have suggested that fires in and around the Mexico City basin can impact air quality (Molina et al., 2007; Bravo et al., 2002; Salcedo et al., 2006). During the springtime (March-May), many fires occur in the pine forests on the mountains surrounding the city, both inside and outside the basin. These fires are virtually all of human origin. Primarily they originate from accidental means (escaped agricultural/land maintenance fires, escaped campfires, smoking, fireworks, vehi- cles, etc.), with a smaller number originating from intentional ignition (E. Alvarado, Univ. of Washington, personal communication, 2009). Typically, the biomass burning season intensifies in late March, reaching a maximum in May (Fast et al., 2007; Bravo et al., 2002). The heat from these fires is observable from space by the infrared channels of the moderate resolution imaging spectroradiometer (MODIS) instruments operated from NASA's Aqua and Terra platforms (Giglio et al., 2003). Figure 1, for example, shows two visible images from MODIS taken on 5 March (panel a) and 10 March (panel b) 2006. The locations of the detected thermal anomalies are shown as red boxes. The aerosol haze from the fires can be seen covering large areas of land around and above MC, particularly on 5 March. MODIS imagery suggests that the total biomass burning around MC in March 2006 was greater than climatological amounts, and closer to what is normally observed during the month of April.

Using tracers of pollution from biomass burning and urban emissions, we show that fires significantly impacted air quality above and downwind of Mexico City in March 2006. We use aircraft measurements of hydrogen cyanide $(\mathrm{HCN})$ to estimate the contribution of biomass burning to the regional air quality. $\mathrm{HCN}$ is produced in the pyrolysis of amino acids (Ratcliff et al., 1974) and has been widely used as an atmospheric tracer of biomass burning emissions (e.g., Li et al., 2003). We use simultaneous observations of acetylene $\left(\mathrm{C}_{2} \mathrm{H}_{2}\right)$ to characterize the contribution of urban 

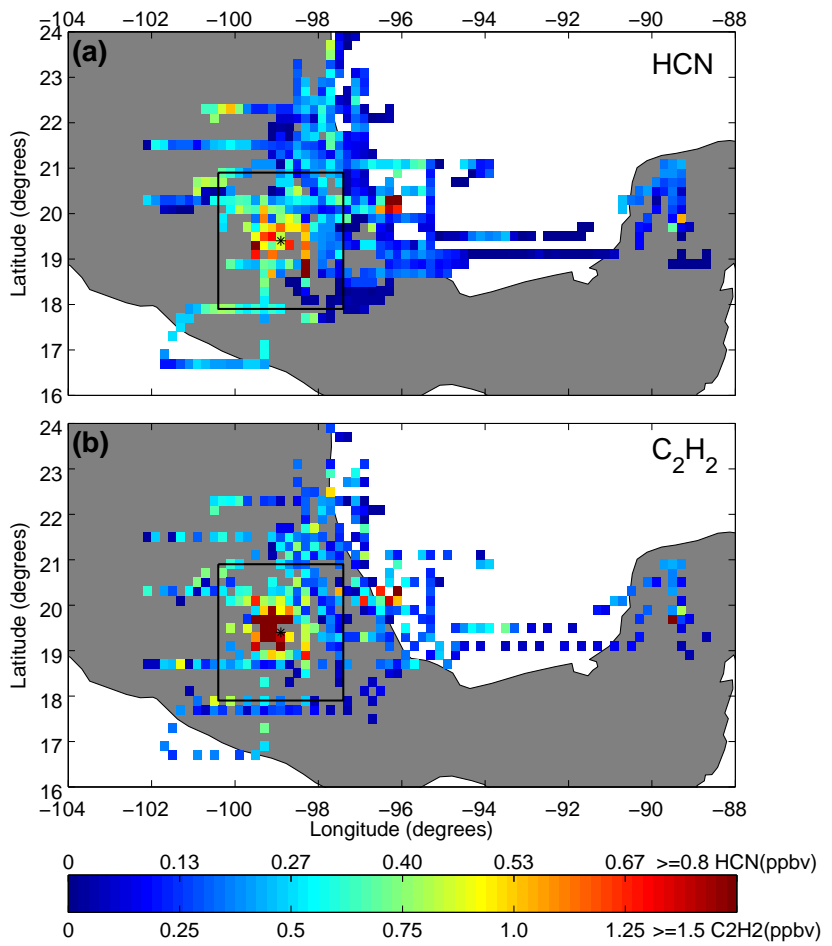

Fig. 2. C-130 flight tracks during MILAGRO colored by tracers: (a) observed $\mathrm{HCN}-\mathrm{HCN}_{\text {background, }}$, and (b) observed $\mathrm{C}_{2} \mathrm{H}_{2}$. The map has been divided into $0.2 \times 0.2$ degree pixels and all observations from the $\mathrm{C}-130$ across the MILAGRO campaign within a given pixel have been averaged together. High concentration data have been rounded down to capped values of 800 and $1500 \mathrm{ppbv}$ for $\mathrm{HCN}$ and $\mathrm{C}_{2} \mathrm{H}_{2}$, respectively. Color scales range from $0 \mathrm{ppbv}$ (dark blue) to the capped value (dark red). The black star in each panel is the center of Mexico City, and the black box outlines the $3 \times 3$ degree box centered on Mexico City which is the study area considered for the fire impact analysis.

emissions. We show that a simple two end-member mixing model (biomass burning and urban emissions) developed from these tracers can explain most of the observed variability in several pollutants including carbon monoxide, benzene, organic aerosol, reactive nitrogen oxides $\left(\mathrm{NO}_{\mathrm{y}}\right)$, and the amount of submicron aerosol particles.

\section{Observations}

The NSF C-130 flew through the Mexico City region on eleven flights in March 2006 (Fig. 2). Of these flights, three had fewer than ten samples of $\mathrm{C}_{2} \mathrm{H}_{2}$ within our study area $(3 \times 3$ degree box centered on MC, shown in Fig. 2 and termed Central Mexican Plateau) and one flight did not have HCN observations. These flights are excluded from the calculation of the overall fire impact $(4,12,26$, and 28 March). In Fig. 2a, the aircraft flight tracks are col-
Table 1. Anthropogenic and biomass burning emission ratios derived here (TLS) and those measured directly in the Mexico City area.

\begin{tabular}{lcccc}
\hline & \multicolumn{2}{c}{ Urban } & \multicolumn{2}{c}{ Biomass Burning } \\
Species & \multicolumn{2}{c}{$\left(\Delta[x] / \Delta\left[\mathrm{C}_{2} \mathrm{H}_{2}\right]\right)^{\mathrm{a}}$} & \multicolumn{2}{c}{$(\Delta[x] / \Delta[\mathrm{HCN}])^{\mathrm{a}}$} \\
& opt $^{\mathrm{b}}$ & 29 March & opt $^{\mathrm{b}}$ & fire obs. \\
\hline $\mathrm{CO}$ & $96 \pm_{2}^{3}$ & 92 & $104 \pm_{9}^{8}$ & 117 \\
$\mathrm{C}_{6} \mathrm{H}_{6}$ & $0.137 \pm_{0.005}^{0.005}$ & 0.13 & $0.19 \pm_{0.01}^{0.01}$ & - \\
$\mathrm{NO}_{\mathrm{y}}$ & $4.3 \pm_{0.3}^{0.3}$ & 3.7 & $5.4 \pm_{1.0}^{1.0}$ & $7.1^{\mathrm{f}}$ \\
$\mathrm{OA}$ & $3.9 \pm_{0.6}^{1.0}$ & 2.9 & $22 \pm_{4}^{4}$ & 14 \\
scattering & $22 \pm_{3}^{4}$ & 22 & $75 \pm_{7}^{6}$ & 78 \\
$\mathrm{HCN}$ & - & $0.056^{\mathrm{c}}$ & $-1-$ & $-1-$ \\
$\mathrm{C}_{2} \mathrm{H}_{2}$ & $-1-$ & $-1-$ & - & 0.17 \\
\hline
\end{tabular}

a Units are $\mathrm{mol} / \mathrm{mol}$, except for $d[\mathrm{OA}] / d[y]$ and $d[\mathrm{scat}] / d[y]$, which have units of $\mu \mathrm{g} \mathrm{sm}^{-3} \mathrm{ppbv}^{-1}$ and $\mathrm{Mm}^{-1} \mathrm{ppbv}^{-1}$, respectively.

${ }^{b}$ Calculated emission ratios determined from TLS anaylsis.

c An upper limit for how much HCN comes from urban emissions in MC, derived from data collected from C-130 on 29 March 2007, a day with low BB influence. This factor is not optimized.

$\mathrm{d}$ Median values for fires sampled by the Twin Otter around Mexico City in March 2006 (Yokelson et al., 2007b).

e This refers to submicron scattering measured at $550 \mathrm{~nm}$.

${ }^{f}$ This value is the $\mathrm{NO}_{\mathrm{x}} / \mathrm{HCN}$ emission ratio, not $\mathrm{NO}_{\mathrm{y}} / \mathrm{HCN}$. For this comparison we assume that in the fresh smoke sampled by Yokelson et al. (2007b), $\mathrm{NO}_{\mathrm{x}} \approx \mathrm{NO}_{\mathrm{y}}$.

ored by the average amount of $\mathrm{HCN}$ measured in the air. Acetonitrile $\left(\mathrm{CH}_{3} \mathrm{CN}\right)$ mixing ratios, which also have been used extensively as a biomass burning tracer, were highly correlated $\left(r^{2}=0.78\right)$ with overall regression slope of 0.39 $\left(\triangle \mathrm{CH}_{3} \mathrm{CN} / \triangle \mathrm{HCN}\right)$ (Fig. A1), similar to several previous measurements of biomass burning emission ratios (Yokelson et al., 2007a; Singh et al., 2003). The mean mixing ratio of $\mathrm{HCN}$ in the study area (7 flights considered, within the $3 \times 3$ degree box) was measured to be $530 \mathrm{pptv}$, about $390 \mathrm{pptv}$ higher than the background values observed in clean air encountered above the plateau pollution.

Figure $2 \mathrm{~b}$ shows the $\mathrm{C}-130$ flight tracks colored by the mixing ratio of $\mathrm{C}_{2} \mathrm{H}_{2} \cdot \mathrm{C}_{2} \mathrm{H}_{2}$ is produced in the combustion of both gasoline and diesel fuels. We chose $\mathrm{C}_{2} \mathrm{H}_{2}$ as our urban tracer because its atmospheric lifetime is quite long. We calculate that with respect to its major loss mechanism (reaction with the hydroxyl radical, $\mathrm{OH}$ ), the atmospheric lifetime is ten days to two weeks in the Mexico City region. We did not use other tracers of city emissions such as toluene or methyl tert-butyl ether (MTBE) because their shorter atmospheric lifetimes complicate the regional analysis. In fresh city plumes (as determined by the ratio of toluene to $\mathrm{C}_{2} \mathrm{H}_{2}$ ), all the urban tracers (e.g. $\mathrm{C}_{2} \mathrm{H}_{2}$, MTBE, toluene) are highly correlated.

Although the regions of enhanced $\mathrm{C}_{2} \mathrm{H}_{2}$ and $\mathrm{HCN}$ appear geographically coincident in Fig. 2, the sources of these 

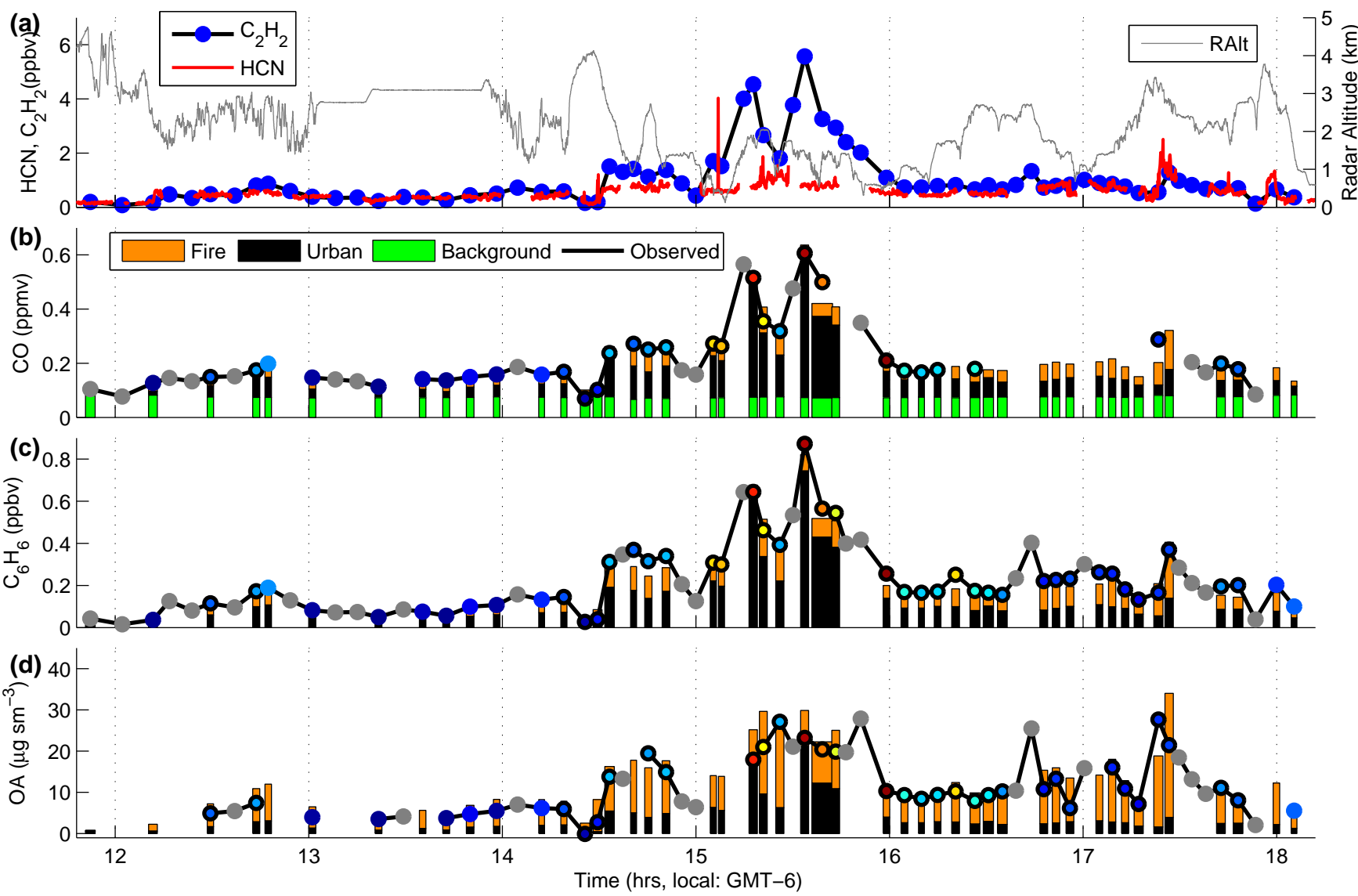

Fig. 3. Timeline from the flight of 8 March 2006: (a) measured $\mathrm{HCN}, \mathrm{C}_{2} \mathrm{H}_{2}$, and radar altitude. The observed (dots) and reconstructed (bars) $\mathrm{CO}$, benzene, and organic aerosol concentrations, are shown in panels (b-d), respectively. The bar widths represent the relative bottle sampling time (width has been expanded by $3 \times$ for clarity). The measurements in panels (b-d) are colored by [toluene]/[ $\left.\mathrm{C}_{2} \mathrm{H}_{2}\right]^{*}$ with color scale ranging from red $=1$ to blue $=0$, and grey meaning data was unavailable for this calculation. Data points with black borders in panels (b-d) lie within the $3 \times 3$ degree study area.

gases within the basin are geographically (and temporally) distinct and significant differences in their distribution can be observed on smaller spatial scales. This is illustrated in Fig. 3a. On 8 March 2006, the C-130 flew into the Mexico City basin and over a short period encountered air masses significantly enhanced in either $\mathrm{HCN}, \mathrm{C}_{2} \mathrm{H}_{2}$, or both (panel a). Fig. 4 shows the flight track corresponding with data shown in Fig. 3 on top of the MODIS - Aqua image for 8 March.

To quantify the contribution of both fire and urban emissions to the distribution of a trace gas (or aerosol), $Y$, we implement a simple two end-member model using the measured excess $\mathrm{HCN},[\mathrm{HCN}]^{*}$, and measured excess $\mathrm{C}_{2} \mathrm{H}_{2},\left[\mathrm{C}_{2} \mathrm{H}_{2}\right]^{*}$, as tracers:

$Y=F_{Y}($ fire $) \times[\mathrm{HCN}]^{*}+F_{Y}($ urban $) \times\left[\mathrm{C}_{2} \mathrm{H}_{2}\right]^{*}$

where,

$[\mathrm{HCN}]^{*}=[\mathrm{HCN}]-S_{\mathrm{HCN}}($ urban $) \times\left[\mathrm{C}_{2} \mathrm{H}_{2}\right]^{*}-[\mathrm{HCN}]_{\text {background }}$
$\left[\mathrm{C}_{2} \mathrm{H}_{2}\right]^{*}=\left[\mathrm{C}_{2} \mathrm{H}_{2}\right]-S_{\mathrm{C}_{2} \mathrm{H}_{2}}($ fire $) \times[\mathrm{HCN}]^{*}-\left[\mathrm{C}_{2} \mathrm{H}_{2}\right]_{\text {background }}$

$F_{Y}$ are scalars that relate the emission of $Y$ from fire and urban sources to the emissions of $\mathrm{HCN}$ and $\mathrm{C}_{2} \mathrm{H}_{2}$, respectively (Table 1). $S_{\mathrm{HCN}}$ and $S_{\mathrm{C}_{2} \mathrm{H}_{2}}$ are the emission ratios of $\mathrm{HCN}$ to $\mathrm{C}_{2} \mathrm{H}_{2}$ and $\mathrm{C}_{2} \mathrm{H}_{2}$ to $\mathrm{HCN}$ for urban and fire emissions, respectively. These cross terms account for the contribution of urban and fire emissions to the excess $\mathrm{HCN}$ and $\mathrm{C}_{2} \mathrm{H}_{2}$, respectively. We also account for the amounts of these tracers advected into the region from afar (backgrounds).

We derive a set of emission ratios, $F_{Y}$, for the pollutants using total least squares (TLS) analysis (Table 1). We weight $[\mathrm{HCN}]^{*}$ and $\left[\mathrm{C}_{2} \mathrm{H}_{2}\right]^{*}$ by estimates of their error determined primarily from uncertainties in the backgrounds and in the variability of the emission ratios. We estimate the uncertainty in the derived emission ratios using a bootstrap method (Efron and Tibshirani, 1993). The bootstrap method creates $x$ alternate data sets by picking $n$ random samples with replacement from the original data set, where $n$ equals the 
number of samples in the original data set. The TLS analysis is then performed across all alternate data sets, and statistics are computed on the results of all analyses. For this analysis we used $x=1000$. In Table 1, we also summarize the emission factors determined independently from measurements made directly in biomass burning plumes measured in the basin during MILAGRO.

Gasoline and diesel engine exhaust contain HCN, though previous measurements of the emissions vary by orders of magnitude (Baum et al., 2007). Automobiles lacking catalytic converters can produce 100 times more $\mathrm{HCN}$ than automobiles with functional catalysts (Baum et al., 2007; Harvey et al., 1983). To estimate the appropriate emission ratio for Mexico City, $S_{\mathrm{HCN}}$, we use observations made from the C-130 on 29 March when the C-130 sampled city emissions with what appears to be minimal fire influence (Fast et al., 2007). The measured slope of $\mathrm{HCN}$ to $\mathrm{C}_{2} \mathrm{H}_{2}$ in the city plumes encountered on this day is $0.056(\mathrm{~mol} / \mathrm{mol})$. The ratio of $\mathrm{CH}_{3} \mathrm{CN}$ to $\mathrm{HCN}$ in the city emissions is 0.5 , similar to the ratio measured in both fire plumes and in the region as a whole. This is in contrast to observations from Asia where urban emissions had a much lower ratio $\mathrm{CH}_{3} \mathrm{CN}$ to $\mathrm{HCN}$ ( $\mathrm{Li}$ et al., 2003). Thus it is possible that even on the 29th, some of the $\mathrm{HCN}$ is from burning. Given our cross term corrections, and assuming urban fire sources such as garbage, coal, and biofuel burning was no different on 29 March than on other days, emissions from these urban fire sources are counted as urban emissions and not as fire emissions. Using the $0.056(\mathrm{~mol} / \mathrm{mol})$ as an upper limit for the $\mathrm{HCN} / \mathrm{C}_{2} \mathrm{H}_{2}$ emission ratio from urban emissions, we estimate that all urban emissions of HCN account for no more than $15 \%$ of the total emissions in the basin during March 2006. Other sources of HCN from, for example, coal burning and petrochemical industries are also estimated to be small (see Appendix A2).

We use measurements of $\mathrm{C}_{2} \mathrm{H}_{2}$ and $\mathrm{HCN}$ observed in forest fires in and around Mexico City to estimate $S_{\mathrm{C}_{2} \mathrm{H}_{2}}$ (Yokelson et al., 2007b). The emission of $\mathrm{C}_{2} \mathrm{H}_{2}$ from these forest fires was near the low end of the range typically observed for extratropical forest fires (Yokelson et al., 2007b; Andreae and Merlet, 2001). We estimate that the contribution of biomass burning to $\mathrm{C}_{2} \mathrm{H}_{2}$ accounts for less than $10 \%$ of the $\mathrm{C}_{2} \mathrm{H}_{2}$ in and around Mexico City.

To account for the background amounts of $\mathrm{C}_{2} \mathrm{H}_{2}$ and $\mathrm{HCN}$ advected into to the region, we use our observations in air sampled aloft, away from the Mexico City basin. We use separate $\mathrm{HCN}$ and $\mathrm{C}_{2} \mathrm{H}_{2}$ backgrounds for the gas phase species and for organic aerosol/scattering, as aerosols have a more variable atmospheric lifetime. For the gas phase species $\left(\mathrm{CO}\right.$, benzene, and $\mathrm{NO}_{\mathrm{y}}$ ), we use a constant value of $140 \mathrm{pptv}$ for the background values of $\mathrm{HCN}$ for flights before 21 March. Following a shift in weather on 21-22 March (Fast et al., 2007) (see also Figs. A5-A7, and supplementary material (http://www.atmos-chem-phys.net/9/4929/ 2009/acp-9-4929-2009-supplement.pdf) for higher resolution MODIS images), we find higher background concentra-

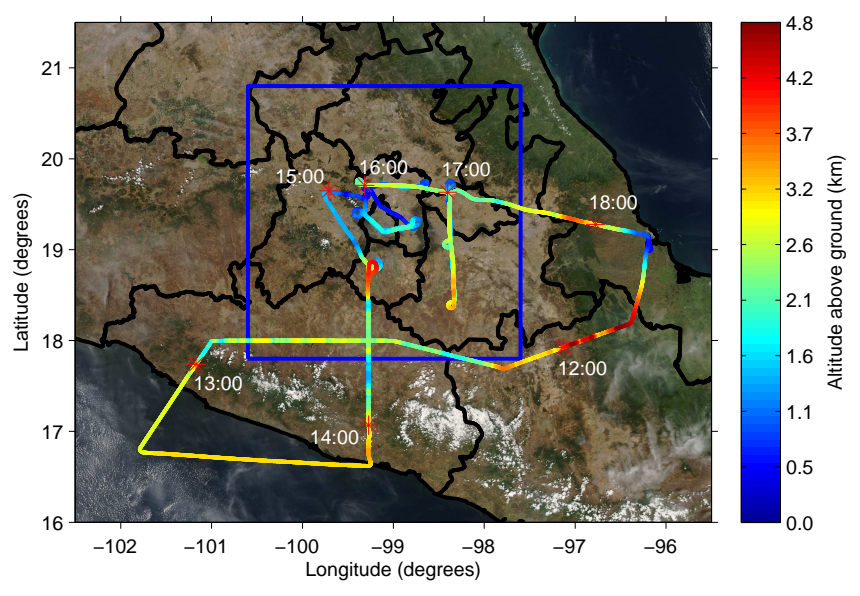

Fig. 4. MODIS-Aqua image and C-130 flight track from 8 March 2006, as accompanyment to Fig. 3. Flight track is colored by aicraft radar altitude (altitude above the ground). Specific times along the flight track are shown as red asterisks, and labeled as local time in hours (GMT-6). The blue box encompasses the $3 \times 3$ degree study area.

tions for $\mathrm{HCN}$ ( 220 pptv). $\mathrm{C}_{2} \mathrm{H}_{2}$ backgrounds are quite small (0-30 pptv), so we have used a constant background value of 0 pptv for the analysis of the gas phase species. For organic aerosol and scattering, we have used a flight-by-flight analysis of the correlation of organic aerosol mass and scattering with $\mathrm{HCN}$ and $\mathrm{C}_{2} \mathrm{H}_{2}$ to define the background $\mathrm{HCN}$ and $\mathrm{C}_{2} \mathrm{H}_{2}$. For flights in early March, the implied background of $\mathrm{HCN}$ and $\mathrm{C}_{2} \mathrm{H}_{2}$ for organic aerosol (the abundance of these gases when the amount of organic aerosol is zero) is very close to the global backgrounds used in the analysis of the gases, but following the rainy period, 20-26 March, the apparent backgrounds for both $\mathrm{HCN}$ and $\mathrm{C}_{2} \mathrm{H}_{2}$ increased more drastically than for the gas phase pollutants; organic aerosol concentrations were near zero at significantly higher concentrations of $\mathrm{HCN}$ and $\mathrm{C}_{2} \mathrm{H}_{2}$ (300 and 150 pptv, respectively). This difference is likely due to removal of aerosol (but not insoluble gases such as $\mathrm{HCN}, \mathrm{CO}, \mathrm{C}_{2} \mathrm{H}_{2}$, etc.) in the region during the rain storms.

The variance in the abundance of our fire and urban tracers $\left(\mathrm{HCN}\right.$ and $\left.\mathrm{C}_{2} \mathrm{H}_{2}\right)$ explains most of the variability in $\mathrm{CO}$ and other pollutants. For example, in panels (b), (c), and (d) of Fig. 3, we show the observations (circles) for CO, benzene, and organic aerosol mass along the C-130 flight track. The observations are averaged to the sampling time of the whole air samples used to determine $\mathrm{C}_{2} \mathrm{H}_{2}$. The bars show the contributions from fire and urban emissions, estimated from $[\mathrm{HCN}]^{*}$ (orange) and acetylene, $\left[\mathrm{C}_{2} \mathrm{H}_{2}\right]^{*}$ (black) using the emission ratios described in Table 1 and the mixing model described by Eq. (1).

Figure 5a shows a scatter plot of the predictions from the two component model and all observations (from all flights) 

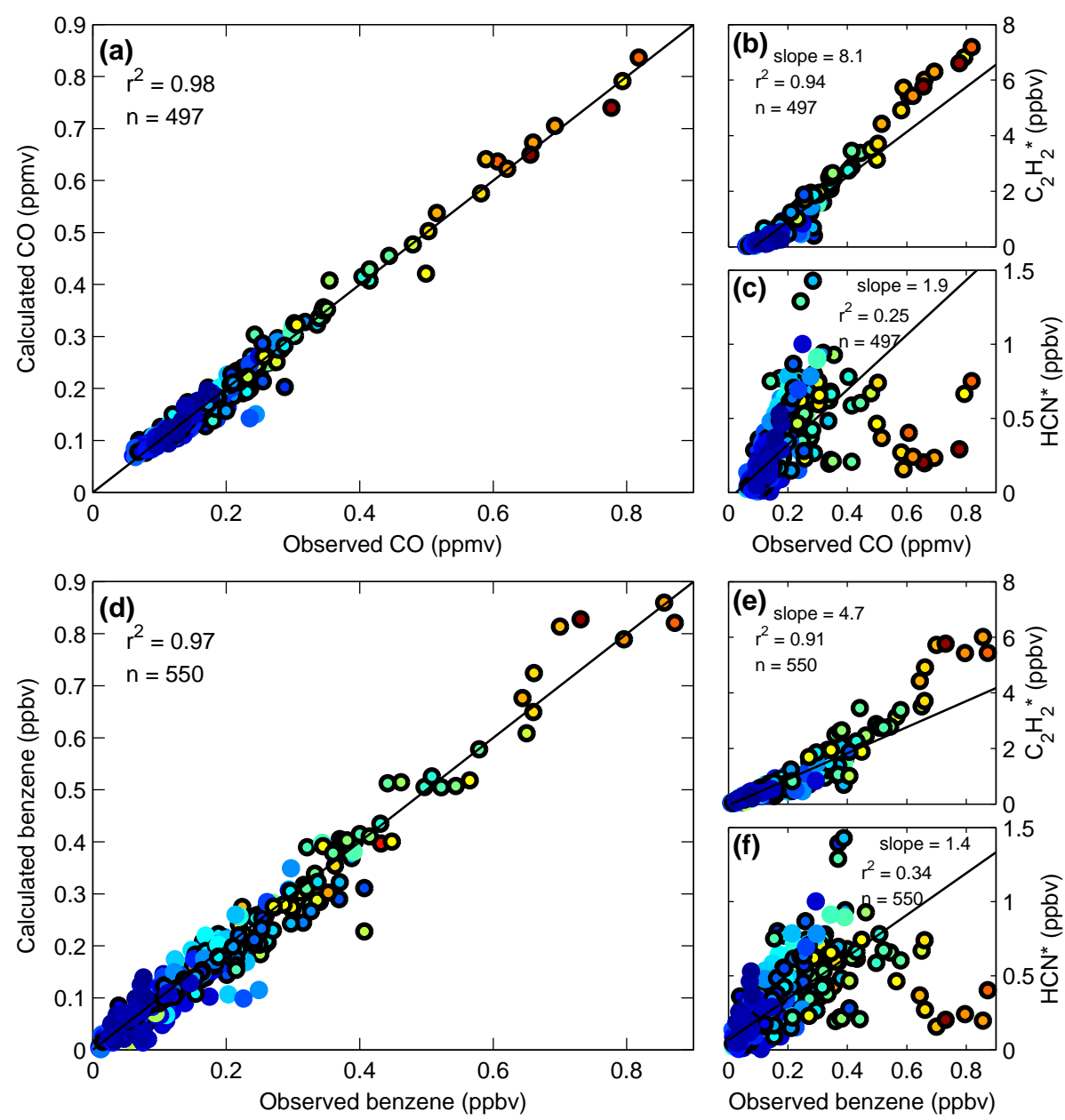

Fig. 5. Scatter plots for observed vs. reconstructed $\mathrm{CO}(\mathbf{a})$ and benzene (d). Associated scatter plots for $\mathrm{CO}$ vs. each tracer, $\left[\mathrm{C}_{2} \mathrm{H}_{2}\right]^{*}(\mathbf{b})$ and $[\mathrm{HCN}]^{*}$ (c) and for benzene vs. each tracer, $\left[\mathrm{C}_{2} \mathrm{H}_{2}\right]^{*}(\mathbf{e})$ and $[\mathrm{HCN}]^{*}$ (f). Lines are best fit to all data using total least squares (TLS) regression. Points are colored by [toluene]/[$\left[\mathrm{C}_{2} \mathrm{H}_{2}\right]^{*}$, where red $=1$ and blue $=0$. Points with black border lie within the $3 \times 3$ degree study area.

made from the $\mathrm{C}-130$ during MILAGRO for $\mathrm{CO}$. The observations made within the $3 \times 3$ degree box surrounding $\mathrm{MC}$, during the 7 flights considered in this analysis are highlighted with a black border. $\mathrm{CO}$ has a relatively long lifetime in the atmosphere and there is a persistent northern hemispheric background of between 60 and $150 \mathrm{ppb}$ that varies with season and latitude. To estimate the regional increase in [CO], we assume that the background $[\mathrm{CO}]$ is equal to the simulation of background CO taken from the Model for OZone And Related chemical Tracers (MOZART) chemical transport model (Horowitz et al., 2003), plus a constant $34 \mathrm{ppbv}$ offset (see Fig. 3b, green bars). The offset was determined from the bias between MOZART simulations and the observed CO in the cleanest air encountered during MILAGRO - typically aloft and outside the Mexico City basin. Figure 5d shows the comparison for benzene. From the tracer analysis, we estimate that biomass burning accounts for $(31 \pm 3) \%$,
$(36 \pm 3) \%$, and $(34 \pm 7) \%$ of the $\mathrm{CO}$, benzene, and reactive nitrogen $\left(\mathrm{NO}_{\mathrm{y}}\right)$. These estimates are the mean of the massweighted, daily-averaged fire/excess fractions for observations made within the $3 \times 3$ degree box centered on MC, for the seven flights considered in this analysis. The sensitivity of these ratios to the size of the box is described in Table A1. Consistent with expectation, the fraction of pollution from biomass burning is lower for a smaller box centered over the city.

Figure 6a shows a scatter plot of the predictions from the two component model for organic aerosol. The data are colored by the ratio of toluene to acetylene. High ratios (red colors) are indicative of very fresh emissions with little photochemical processing. A similar figure for submicron aerosol scattering is shown as Fig. A3. From the tracer analysis, we estimate that biomass burning accounts for $(66 \pm 11) \%$, and $(57 \pm 5) \%$ of the organic aerosol mass and total submicron 

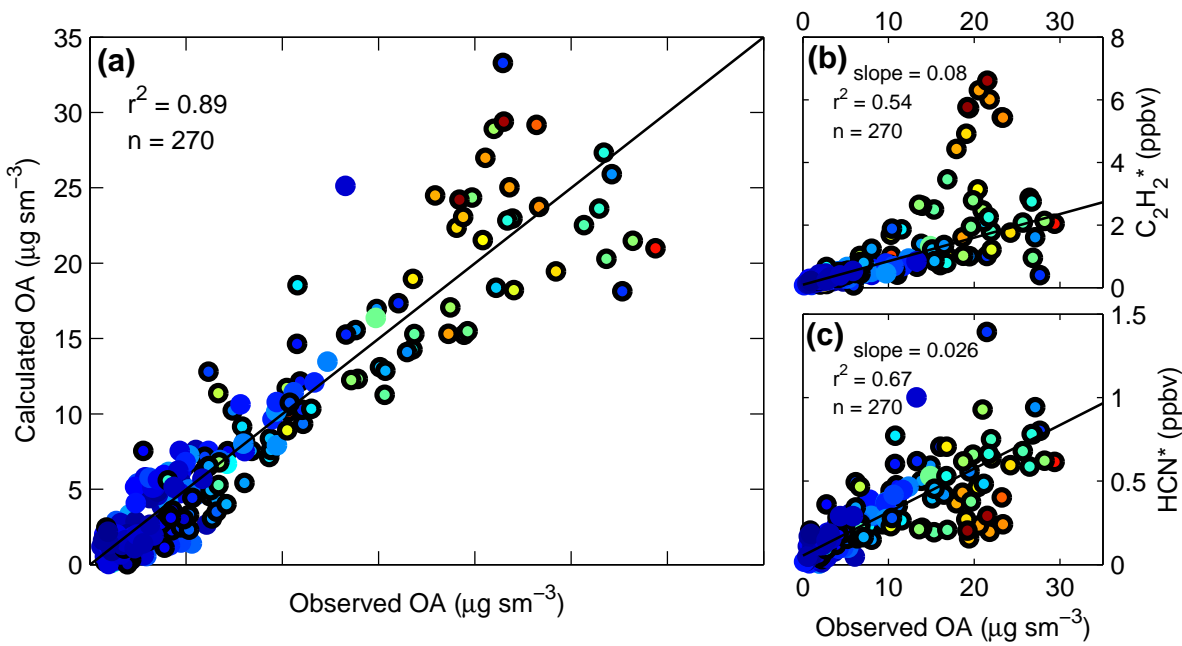

Fig. 6. Scatter plot for observed vs. reconstructed OA (a). Associated scatter plots for OA vs. each tracer, $\left[\mathrm{C}_{2} \mathrm{H}_{2}\right]^{*}(\mathbf{b})$ and $[\mathrm{HCN}]^{*}(\mathbf{c})$. Lines are best fit to all data using total least squares (TLS) regression. Points are colored by [toluene $] /\left[\mathrm{C}_{2} \mathrm{H}_{2}\right]^{*}$, where red $=1$ and blue $=0$. Points with black border lie within the $3 \times 3$ degree study area.

scattering (which determines visibility). These estimates are the mean of the mass-weighted, daily-averaged fire/excess fractions for observations made within the $3 \times 3$ degree box centered on $\mathrm{MC}$ for the seven flights considered in this analysis.

\section{Discussion}

In Table 1, we compare the emission ratios estimated from the TLS analysis with observations made in the city plume encountered on 29 March (little BB influence) and in fresh fire plumes sampled within the study area by the Twin Otter (Yokelson et al., 2007b). The emission ratios derived here do not change if the data from the 29th are excluded from the least-squares analysis. Note, while Yokelson et al. (2007b) report emission factors for up to 5 fires (or groups of fires) as well as the geometric mean of the reported individual emission factors, here we report (Table 1) the median values of the individual emission ratios calculated from the emission factors given therein. Median values are reported here because of the high variability of the individual emission factors, and the non-uniform weighting across fires in the geometric mean calculation. In particular, the unusually high modified combustion efficiency (MCE) of the "17 March - Planned Fire" and the group of fires reported as " 6 March - Fires 1-4" are given $25 \%$ of the weight as the remainder of the fires in calculating the geometric mean. While not as good, the comparison using the mean of the emission ratios derived from Yokelson et al. (2007b) does not alter the conclusions.

The urban ratio of $\mathrm{CO}$ to $\mathrm{C}_{2} \mathrm{H}_{2}$ measured on 29 March, $92(\mathrm{~mol} / \mathrm{mol})$, is very close to the emission ratio estimate from the total least squares (TLS) analysis, $96(\mathrm{~mol} / \mathrm{mol})$
(Table 1). This ratio is lower than typically observed in US $(300-500 \mathrm{~mol} / \mathrm{mol})$, and Asian cities $(220 \mathrm{~mol} / \mathrm{mol}$ ) (Xiao et al., 2007), but comparable to the value observed by Grosjean et al. (1998) in urban air in Brazil. The lower emission ratios in Mexico and Brazil may reflect differences in fuel composition or catalytic converter functionality (Sigsby et al., 1987). The relatively high concentration of $\mathrm{C}_{2} \mathrm{H}_{2}$ in traffic exhaust combined with the emissions of $\mathrm{C}_{2} \mathrm{H}_{2}$ from fires near the low end of the typical range makes $\mathrm{C}_{2} \mathrm{H}_{2}$ a good tracer for the Mexican urban emissions. Observations made during the same period of $\mathrm{CO}$ and $\mathrm{C}_{2} \mathrm{H}_{2}$ at a ground station (T1) in Mexico City and described by de Gouw et al. (2009) show a mean $\mathrm{CO}$ to $\mathrm{C}_{2} \mathrm{H}_{2}$ ratio of $150 \mathrm{~mol} / \mathrm{mol}$. It is not known at this time what accounts for this difference, but likely it is due to a difference in calibration factors. The analysis described here is not sensitive to an absolute error in $\mathrm{C}_{2} \mathrm{H}_{2}$ or $\mathrm{CO}$ as the emission ratios are derived internally to the data set. While a calibration error in either $\mathrm{CO}$ or $\mathrm{C}_{2} \mathrm{H}_{2}$ will affect the $\mathrm{C}_{2} \mathrm{H}_{2}$ emission ratios reported in Table 1, it will not change the calculated fire impact for the trace gasses reported in Table A1.

The median ratio of $\mathrm{CO}$ to $\mathrm{HCN}$ observed in biomass burning plumes within the study area, $117 \mathrm{~mol} / \mathrm{mol}$ (Yokelson et al., 2007b), is close to that derived in the total least-squares analysis, $104 \mathrm{~mol} / \mathrm{mol}$. As noted by Yokelson et al. (2007b), this ratio is at the low end of the range typically observed for biomass burning. The relatively high emissions of HCN in biomass burning plumes combined with the low emission ratios from urban sources makes $\mathrm{HCN}$ a very good tracer for biomass burning in Mexico City.

Biomass burning is a significant global source of benzene and the impact of this source in and around the Mexico City 
basin is quite apparent in the correlations of benzene with the tracers (Fig. 5d-f). From the least squares analysis, we estimate that fires contributed $36 \%$ of this pollutant to the atmosphere above the central Mexican Plateau in March 2006. Relative to $\mathrm{CO}$, the benzene emission ratio for biomass burning derived here is similar to those reported in other studies (Andreae and Merlet, 2001). As an aside, measurements of the ratio of benzene and toluene have been used in many previous studies to estimate the aging of an urban airmass as the atmospheric oxidation of toluene occurs much more rapidly than benzene (e.g., Cubison et al., 2006). Because the benzene/toluene emission ratio from fires $(\sim 1-3)$ is much greater than the same emission ratio from urban emissions (0.2), this method is not appropriate for cities - such as Mexico City during the biomass burning season - that have significant contributions of benzene from fire emissions.

Organic aerosol generally accounts for more than half the mass of fine particulate matter $\left(\mathrm{PM}_{2.5}\right)$ in (Salcedo et al., 2006) and around (DeCarlo et al., 2008) Mexico City. As shown in Fig. 6b-c, the amount of organic aerosol is highly correlated with $[\mathrm{HCN}]^{*}$ and $\left[\mathrm{C}_{2} \mathrm{H}_{2}\right]^{*}$, suggestive of large fire and urban emission influences. Using the emission ratios described in Table 1, we estimate that biomass burning contributes $66 \%$ of the organic aerosol to the study area in March 2006. These estimates are quite uncertain, however, due to complex aerosol chemistry.

Organic aerosol is both formed in and lost from the atmosphere on relatively fast timescales. Although direct (or primary) emissions of organic aerosol from automobiles are quite small $(\sim 5-10 \mu \mathrm{g}$ per standard $(T=273 \mathrm{~K}, P=1 \mathrm{~atm})$ cubic meter of air $\left(\mathrm{sm}^{3}\right)$ per ppmv CO (de Gouw et al., 2005; Robinson et al., 2007)), subsequent atmospheric oxidation of co-emitted hydrocarbons such as toluene and other aromatics, as well as biogenic and biomass burning hydrocarbon emissions, can yield low vapor pressure compounds that condense on the existing particulate forming secondary organic aerosol (SOA) (Kroll and Seinfeld, 2008). The amount of SOA produced from these gas-phase sources over the period of a day substantially exceeds the primary emissions from urban sources (de Gouw et al., 2005; Kleinman et al., 2008; Robinson et al., 2007; Volkamer et al., 2006). The influence of this process is apparent in the aircraft data. In Fig. 6a, the organic aerosol data is colored by the ratio of toluene to acetylene. Toluene is co-emitted with acetylene in urban emissions, but is oxidized in the atmosphere with a lifetime of approximately 12 daylight hours. In samples containing very high toluene (less oxidized), the total leastsquares analysis tends to over-predict the amount of organic aerosol. For example, the urban emission ratio derived from the least-squares analysis $\left(\sim 39 \mu \mathrm{g}\right.$ per $\mathrm{sm}^{3}$ per ppmv $\mathrm{CO}$ or $\sim 3.9 \mu \mathrm{g}$ per $\mathrm{sm}^{3}$ per ppbv of $\mathrm{C}_{2} \mathrm{H}_{2}$ ) is greater than the factor derived from the slope of the correlations in the fresh plumes encountered on 29 March.

In addition to aerosol growth, aerosol mass can be lost through several mechanisms. As aerosol is transported away from its source and diluted with clean air, semi-volatile compounds evaporate to the gas phase (Robinson et al., 2007). Dry and wet deposition also remove aerosol from the atmosphere. As mentioned earlier, the changing backgrounds for aerosol relative to insoluble gases observed during late March are likely explained by aerosol loss via wet deposition.

Despite the complexity of the aerosol chemistry, the simple two end-member mixing model does describe much of the variability of organic aerosol mass observed from the C130. This result may be related to our sampling - most of the observations were made in the afternoon when the city and fire emissions had experienced some aging. The apparent organic aerosol emission ratio for urban emissions derived from the 29 March plume, $32 \mu \mathrm{g}$ OA per $\mathrm{sm}^{3}$ per ppmv $\mathrm{CO}$, is not inconsistent with other estimates for organic aerosol from urban emissions aged 3-6 h (de Gouw et al., 2005; Volkamer et al., 2006). The aerosol burden continues to increase as the air masses are further oxidized in the MC outflow (Kleinman et al., 2008); similar to what has been observed in the New York City (de Gouw et al., 2005) and Atlanta plumes (Weber et al., 2007).

The complexity of the mixing of the urban-core aerosol emissions with the regional aerosol emissions (often dominated by fire emissions) as well as mixing with the clean free troposphere precludes strong statements on the aerosol dynamics of these different sources.

The average $\mathrm{NO}_{\mathrm{x}} / \mathrm{VOC}$ emission ratio for the fires surrounding Mexico City is similar to the urban $\mathrm{NO}_{\mathrm{x}} / \mathrm{VOC}$ emission ratio for Mexico City. This is due in part to the higher than expected $\mathrm{NO}_{\mathrm{x}}$ emission from the fires, which is significantly (2-4 times) larger than typical for fires (Yokelson et al., 2007b). As the fire and urban $\mathrm{NO}_{\mathrm{x}} / \mathrm{VOC}$ emissions are similar, the fire emissions will significantly impact the ozone production in the Mexico City outflow. Modeling of the transport and aging of the MC plume using a 3-D chemical transport model with full chemistry and accurate urban and fire emissions will be required to quantify the full impact of the fire emissions on ozone concentrations.

\section{Implications for air quality improvement}

The implications of this study for air quality engineering in Mexico City are not straight forward. Although visibility within the city and the export of aerosol, ozone, and other trace gases is significantly impacted by biomass burning during the period of our observations, it is not possible to estimate from this data set the long-term impact of such burning on the urban dwellers of Mexico City. Biomass burning in March 2006 was significantly higher than typical for March, though not unlike the amount of burning usually observed in the height of the biomass burning in April/May. During most of the year (June-February), however, these sources are negligible. Thus, annually-averaged, the impact 
Table A1. Fire impact for pollutants considering several box sizes.

\begin{tabular}{llcc}
\hline Species & ${\text { Box } 1^{\mathrm{a}}(\%)}$ & ${\text { Box } 2^{\mathrm{b}}(\%)}$ & Box $3^{\mathrm{c}}(\%)$ \\
\hline $\mathrm{CO}$ & 21 & 28 & 31 \\
$\mathrm{C}_{6} \mathrm{H}_{6}$ & 25 & 33 & 36 \\
$\mathrm{NO}_{\mathrm{y}}$ & 24 & 31 & 34 \\
$\mathrm{OA}$ & 52 & 61 & 66 \\
scattering & 43 & 52 & 57 \\
\hline
\end{tabular}

a Box defined by latitude: [19.269 to 19.867] and longitude: [-99.300 to -98.867$]$.

b Box defined by latitude: [19.067 to 20.033] and longitude: [-99.433 to -98.667$]$.

c Box defined by latitude: [17.900 to 20.900] and longitude: [ -100.400 to -97.400$]$.

of biomass burning will certainly be much smaller. In addition, because our sampling was from aircraft and primarily in the afternoon, and because the biomass burning was primarily in the forest above the city (Yokelson et al., 2007b), the impact of fire on the air breathed by people within Mexico City will be smaller than the regional impact estimated here. Indeed, we observe that even in the relatively well mixed afternoon planetary boundary layer, the impact of fire increases with altitude (Fig. A4). Consistent with this finding, estimates of the impact of fire on air quality at the ground stations within the city suggest a smaller fire influence (Molina et al., 2007; Bravo et al., 2002; Salcedo et al., 2006; Yokelson et al., 2007b; Stone et al., 2008; Moffet et al., 2008; Aiken et al., 2009). A possible method for estimating the impact of fires to people on the ground in Mexico City would be through the use of a high resolution 3-D chemical transport model constrained by accurate winds and meteorological conditions, accurate fire emissions, and coupled with population maps. For example, an extension of the Fast et al. (2009) study could provide such an estimate, however additional work would be required to properly model the nighttime and early morning boundary layer, as well as an adequate parameterization of SOA growth which considers both anthropogenic and biomass burning precursors. Finally, unlike reducing emissions from the urban sources, reducing fire emissions through fire suppression efforts may have environmental costs as well as benefits; although forest fire suppression in and around the basin would yield improvement in visibility, such fire suppression actions may be inconsistent with proper forest management practices.

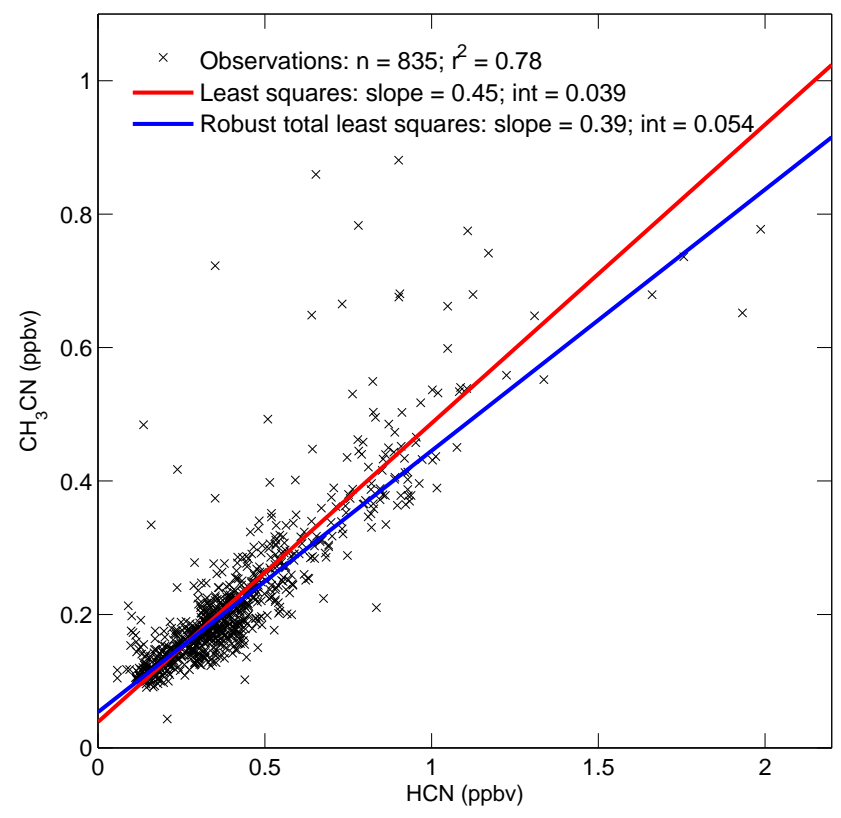

Fig. A1. Scatter plot of the $\mathrm{HCN}$ and the $\mathrm{CH}_{3} \mathrm{CN}$ observations made aboard the $\mathrm{C}-130$ during the MILAGRO experiment $\left(r^{2}=0.78\right)$. The data (black x symbols) were fit using least squares (red: slope $=0.45$, intercept $=0.039 \mathrm{ppbv}$ ), and robust total least squares (blue: slope $=0.39$, intercept $=0.054$ ) regression techniques. Robust least squares is an iterative algorithm using reweighted least squares and a bisquare weighting function, where data which lie far from the best fit are given less weight in successive iterations. The $r^{2}$ value is calculated via the standard method.

\section{Appendix A}

\section{Additional information}

\section{A1 Data sources}

HCN was measured on the NCAR C-130 as discrete $0.5 \mathrm{~s}$ samples obtained every $5 \mathrm{~s}$. The analysis was performed by chemical ionization mass spectrometry (CIMS). While the Caltech CIMS instrument has been described previously in detail (Crounse et al., 2006), the particular HCN method has not. In brief, $\mathrm{HCN}$ reacts rapidly with the $\mathrm{CF}_{3} \mathrm{O}^{-}$ (and $\mathrm{CF}_{3} \mathrm{O}^{-} \cdot \mathrm{H}_{2} \mathrm{O}$ ) anion to form the cluster product ion, $\mathrm{CF}_{3} \mathrm{O}^{-} \cdot \mathrm{HCN}$, which is monitored at $m / z=112$. Instrumental backgrounds were measured once every $15 \mathrm{~min}$ by passing ambient air through a filter containing nylon wool coated with $\mathrm{NaHCO}_{3}$. In-flight calibrations were preformed once per hour using $\mathrm{HNO}_{3}$ and $\mathrm{H}_{2} \mathrm{O}_{2}$ calibration standards and proxied to laboratory calibrations of $\mathrm{HCN}$. Similar to $\mathrm{H}_{2} \mathrm{O}_{2}$, the sensitivity of the CIMS instrument toward $\mathrm{HCN}$ is a function of water vapor. This is corrected for using the aircraft water vapor measurement and a water vapor sensitivity curve for HCN determined in the laboratory. Absolute laboratory calibrations were conducted using $\mathrm{HCN}$ permeation 

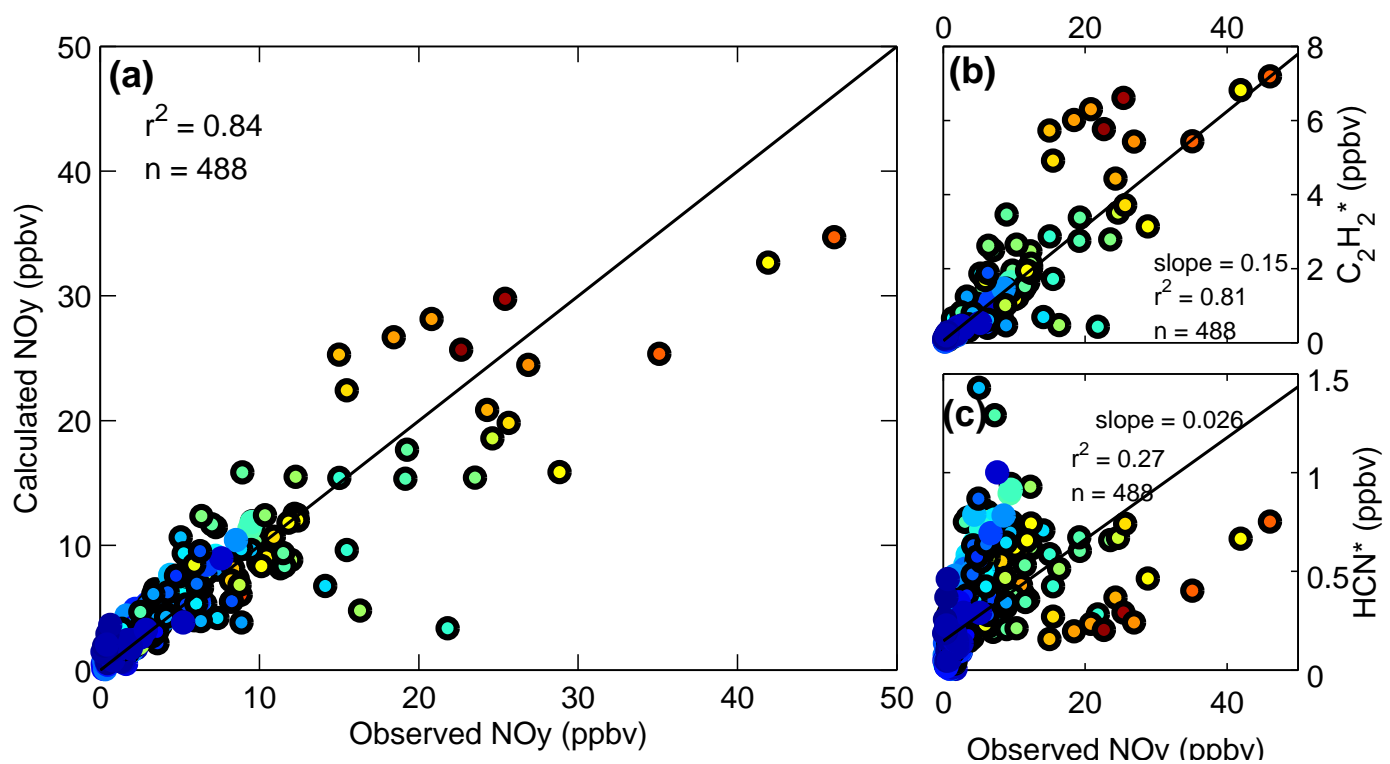

Fig. A2. Scatter plot for observed vs. reconstructed $\mathrm{NO}_{\mathrm{y}}$ (a). Associated scatter plots for $\mathrm{NO}_{\mathrm{y}}$ vs. each tracer, $\left[\mathrm{C}_{2} \mathrm{H}_{2}\right]^{*}(\mathbf{b})$ and $[\mathrm{HCN}]^{*}(\mathbf{c})$.

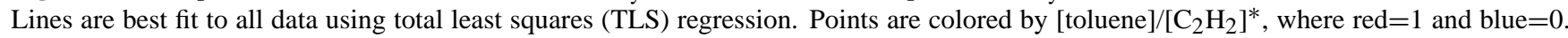
Points with black border lie within the $3 \times 3$ degree study area.
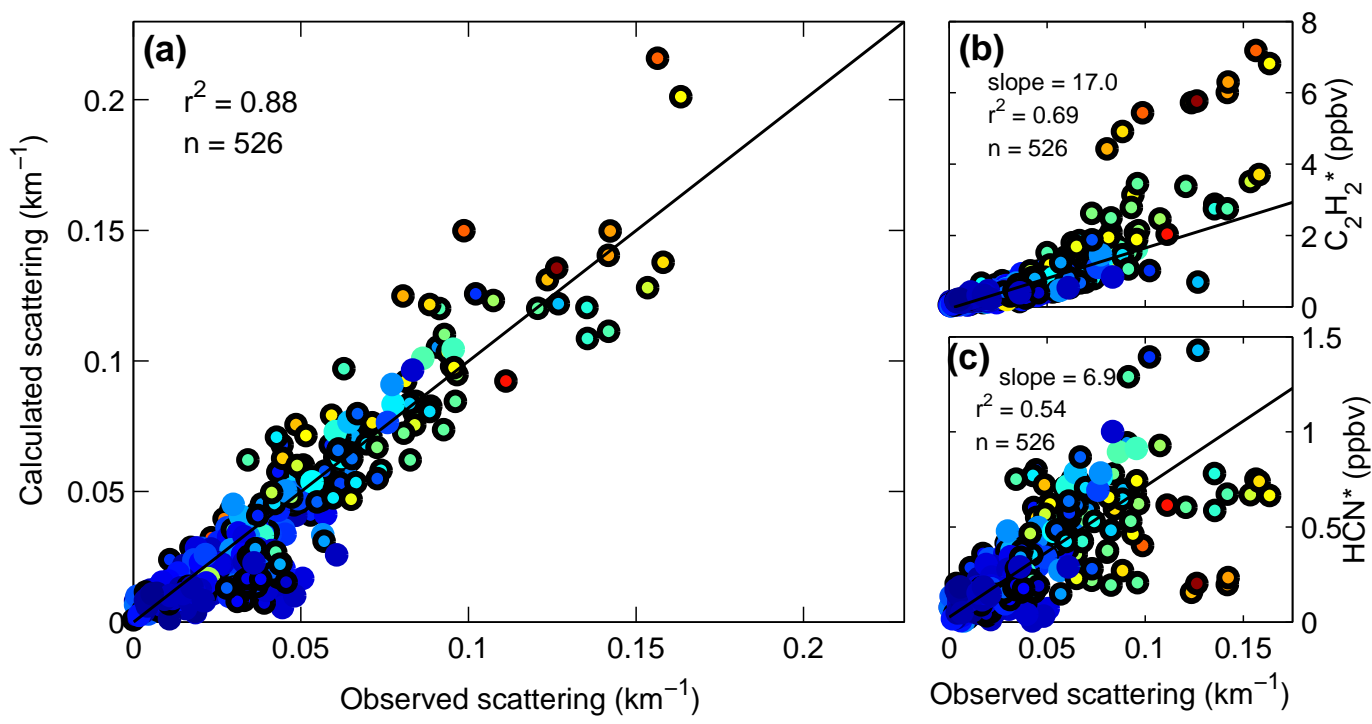

Fig. A3. Scatter plot for observed vs. reconstructed submicron scattering (a). Associated scatter plots for submicron scattering vs. each tracer, $\left[\mathrm{C}_{2} \mathrm{H}_{2}\right]^{*}(\mathbf{b})$ and $[\mathrm{HCN}]^{*}(\mathrm{c})$. Lines are best fit to all data using total least squares (TLS) regression. Points are colored by [toluene]/[C $\left.\mathrm{C}_{2} \mathrm{H}_{2}\right]^{*}$, where red $=1$ and blue $=0$. Points with black border lie within the $3 \times 3$ degree study area.

tubes (KIN-TEC), whose output was determined through both gravimetric and spectroscopic (FTS) means. Both absolute calibration methods agreed within $10 \%$. Considering uncertainties in the absolute laboratory calibrations and water vapor concentration, the accuracy of the HCN observations is estimated to be better than $\pm 30 \%$. The precision is limited mostly by counting statistics (background + signal) and is about $5 \%$ ( 1 standard deviation) at 250 pptv $\mathrm{HCN}$ under low to moderate water vapor levels $\left(\mathrm{H}_{2} \mathrm{O}\right.$ mixing ratio $\leq 0.004$ ) for a $0.5 \mathrm{~s}$ integration period.

$\mathrm{CH}_{3} \mathrm{CN}$ was measured by a cryotrap concentrator coupled to a gas chromatograph mass spectrometer (cryo-GCMS), an instrument similar to the one described by Apel et al. (2003). The cryo-GCMS instrument concentrated ambient air in the 
cryotrap for $45 \mathrm{~s}$ prior to a $125 \mathrm{~s}$ analysis, yielding one data point every $170 \mathrm{~s}$. The accuracy for the cryo-GCMS $\mathrm{CH}_{3} \mathrm{CN}$ determination is estimated to be $\pm 20 \%$ with a precision of $\pm 3 \%$.

$\mathrm{C}_{2} \mathrm{H}_{2}$, benzene, and toluene were recovered from $2 \mathrm{~L}$ canister samples that were periodically filled (approximately 12 samples per hour for the flights into the city). Each canister is filled over a period of $30-120 \mathrm{~s}$. These samples were analyzed by gas chromatography at UC-Irvine (Blake et al., 1997). The detection limit for each of these compounds is 3 pptv, and the accuracy is estimated to be better than $\pm 5 \%$ for $\mathrm{C}_{2} \mathrm{H}_{2}$ and $\pm 10 \%$ for benzene and toluene.

$\mathrm{NO}_{\mathrm{y}}$ was measured via catalytic reduction of reactive nitrogen species to NO on a gold surface in the presence of a small flow of $\mathrm{CO}$, used as a reducing agent. The resulting NO was measured by the standard chemiluminescence technique. In order to keep the conversion efficiency constant the converter was maintained at a constant pressure using a heated teflon valve just upstream of the converter. The converter was housed in the inlet pylon, extending about $30 \mathrm{~cm}$ into the airstream, in order to minimize the length of inlet tubing upstream of the converter. The upstream plumbing (tubing and valve) were limited to a heated length of about $15 \mathrm{~cm}$. The inlet tubing and converter were oriented perpendicular to the airstream with an aft-facing $45^{\circ}$ cut on the end of the tubing. This configuration minimized particle amplification, and tended to exclude larger particles (1 micron or so). At $1 \mathrm{ppbv}$, the estimated $\mathrm{NO}_{\mathrm{y}}$ precision and accuracy are $\pm 3 \%$ and $\pm 15 \%$, respectively.

Carbon monoxide was measured continuously with an vacuum ultraviolet (VUV) fluorescence instrument similar to the one developed by Gerbig et al. (1999) with a precision of 3 ppbv and a typical accuracy of $\pm 10 \%$ at $100 \mathrm{ppbv} \mathrm{CO}$. On several flights, the VUV fluorescence $\mathrm{CO}$ measurements were not available and $\mathrm{CO}$ concentrations were determined from the canister samples.

Aerosol composition (organic, sulfate, nitrate, ammonium, and chloride) and mass were determined with a high resolution aerosol mass spectrometer (HR-AMS) (DeCarlo et al., 2006, 2008). The HR-AMS detection limit for the organic aerosol is $0.35 \mu \mathrm{g} \mathrm{sm}^{-3}$ for a $12 \mathrm{~s}$ integration period, and its accuracy is estimated to be better than $\pm 25 \%$. Aerosol scattering coefficients were measured at 450,550 , and $700 \mathrm{~nm}$ wavelengths using two TSI-3563 nephelometers. One nephelometer measured submicron scattering employing a $1 \mu \mathrm{m}$ aerodynamic impactor, and the other measured total scattering (Anderson et al., 2003).

\section{A2 Alternative HCN sources}

In addition to biomass burning and gasoline/diesel combustion, other sources of HCN may contribute to the enhanced $\mathrm{HCN}$ in the Mexico City basin. For example, HCN has also been shown to be produced in the pyrolysis of coal from the breakdown of pyrrolic and pyridinic nitrogen (Leppalahti and

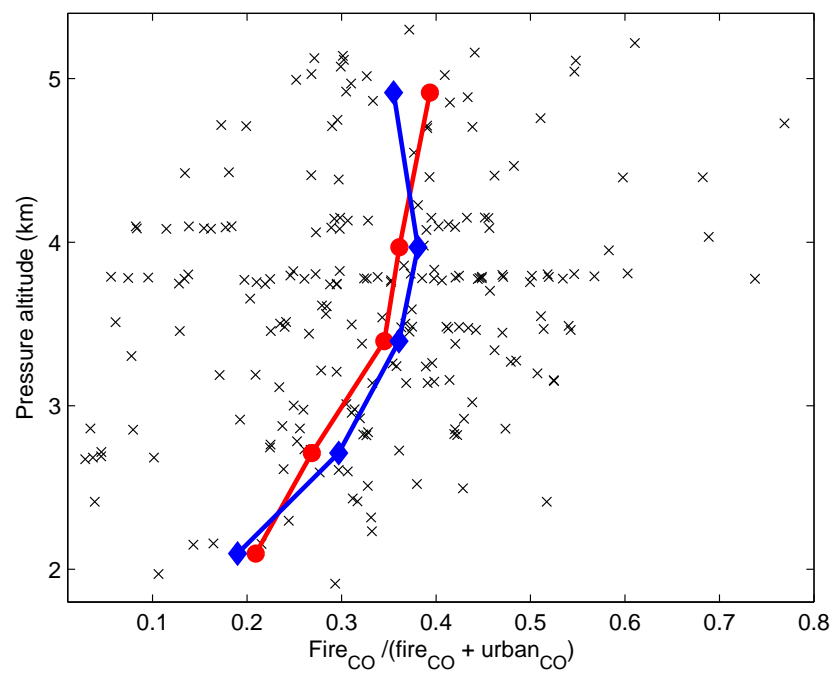

Fig. A4. Altitude dependence of fire $\mathrm{CO}$ over Mexico City region. The fraction of excess $\mathrm{CO}$ (CO-background) which according to the two component analysis comes from biomass burning versus pressure altitude for observations (black $\mathrm{x}$ symbols) made within the $3 \times 3$ degree study area around Mexico City. Note the ground level in MC is at $2.2 \mathrm{~km}$ pressure altitude. The mean (red circles) and median (blue diamonds) averages are shown for $750 \mathrm{~m}$ altitude bins.

Koljonen, 1995). Coal burning, however, is minimal in the basin. According to the 1999 Mexico National Emissions Inventory (NEI), $88 \%$ of the CO produced in Mexico City, and surrounding states (summing over Distrito-Federal, Mexico, and Morales) comes from mobile sources (NEI, 2008).

We did observe elevated HCN in the plumes from the power plants (fuel-oil fired) and petrochemical complex in Tula, north of Mexico City. The ratio of $\mathrm{HCN}$ to $\mathrm{CO}$ in the Tula plume is similar to that from fire. The Tula CO emissions are, however, significantly smaller than the $\mathrm{CO}$ emissions from fire in the MC basin suggesting these emissions have minimal influence on the regional HCN budget.

\section{A3 HCN and acetonitrile correlation}

A reasonable correlation $\left(r^{2}=0.78, n=835\right)$ exists between $\mathrm{HCN}$ and $\mathrm{CH}_{3} \mathrm{CN}$ observations, suggesting similar sources (Fig. A1). However, on multiple occasions, directly over Mexico City, enhanced $\mathrm{CH}_{3} \mathrm{CN}$ was observed without accompanying enhancements in $\mathrm{HCN}$ (see Fig. A1, data excursions well above the best fit line). Explanations for these $\mathrm{CH}_{3} \mathrm{CN}$ plumes could include industrial, non-combustion, sources, or possibly a different compound interfering with the GC-MS $\mathrm{CH}_{3} \mathrm{CN}$ measurement. Overall, $\triangle \mathrm{CH}_{3} \mathrm{CN}$ is $39 \%$ of $\triangle \mathrm{HCN}$ (Fig. A1). On 29 March, a day with little fire influence according to $\mathrm{HCN}$ levels relative to $\mathrm{CO}$, the slope of $\mathrm{CH}_{3} \mathrm{CN}$ to $\mathrm{HCN}$ is similar to the overall relationship, indicating that these compounds are emitted from urban sources 

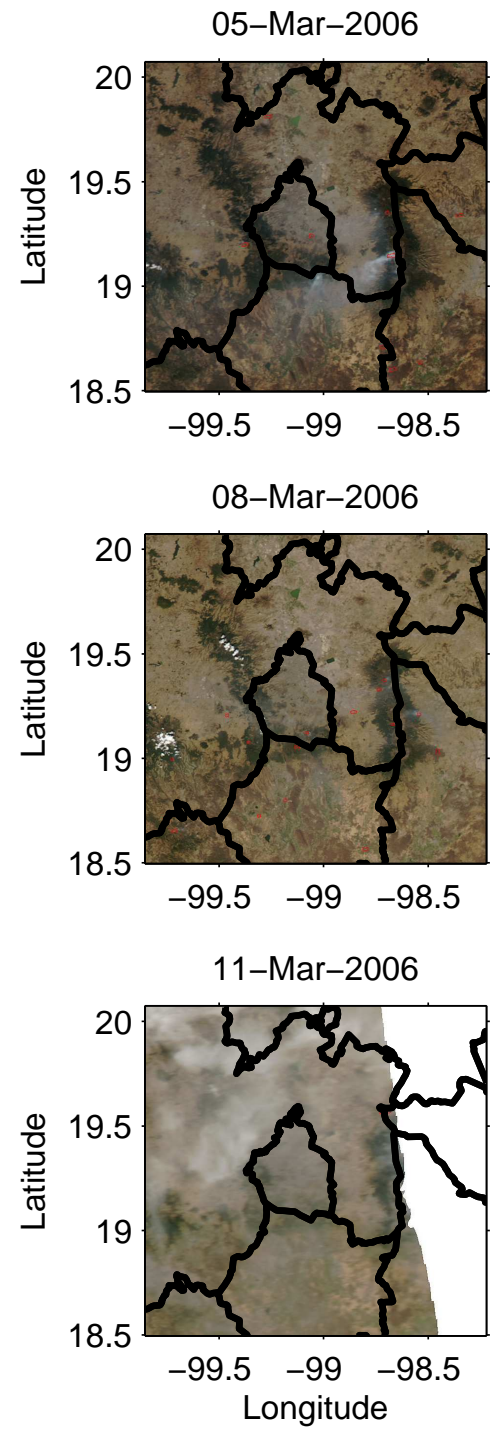
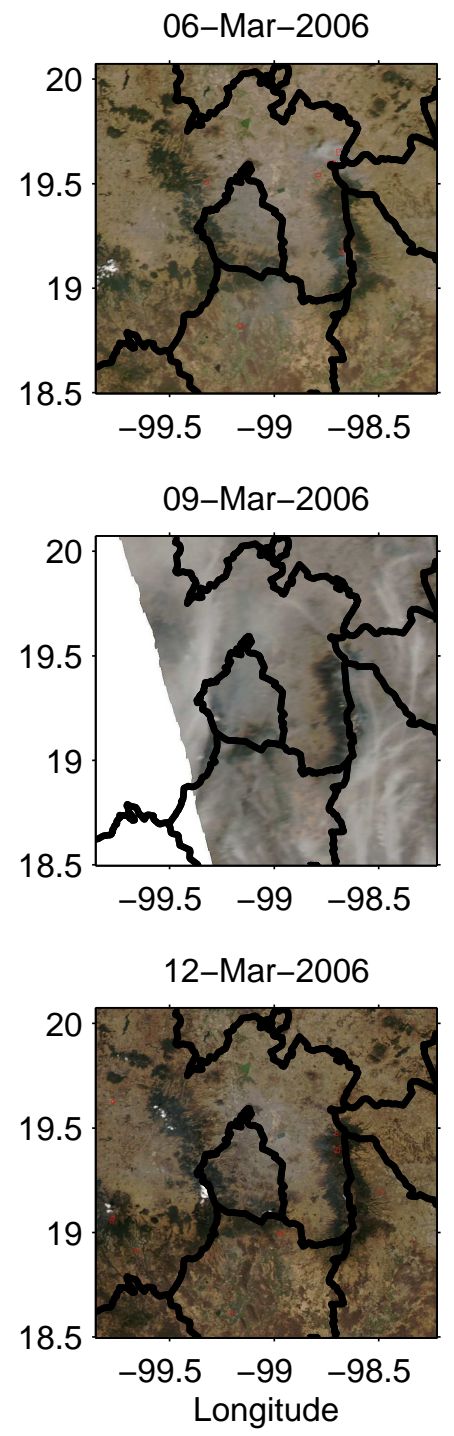
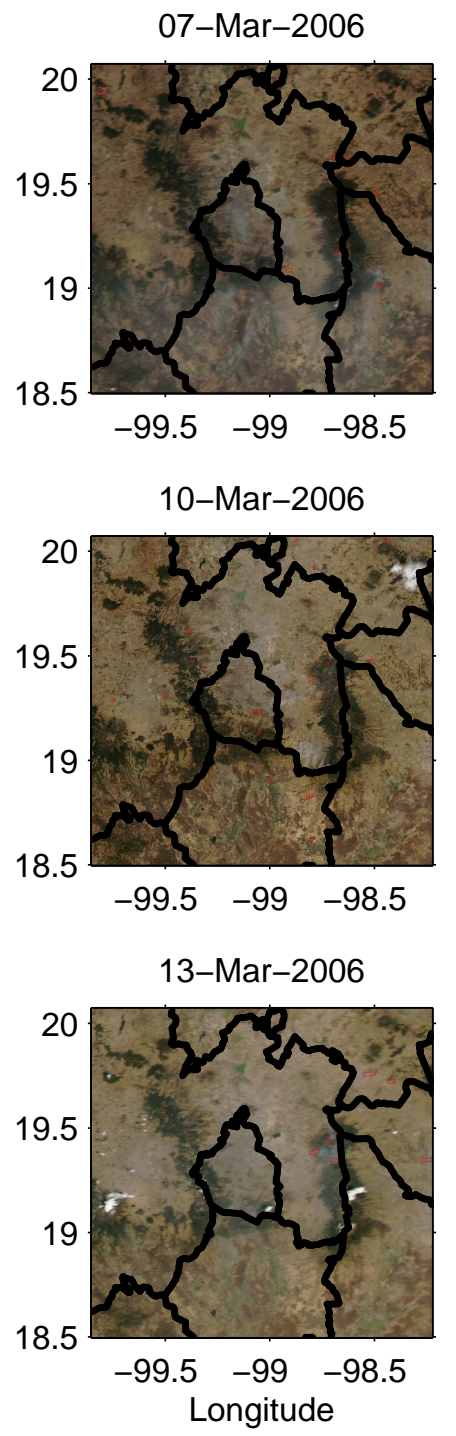

Fig. A5. MODIS-Aqua images around Mexico City for 5 March through 13 March 2006. Red boxes represent detected fires. Black lines are state boundaries. Blank areas represent missing data. Images courtesy of MODIS Rapid Response Project at NASA/GSFC.

in about the same ratio as from fire, or that fire is still the dominating source of these compounds even for days without large fires.

\section{A4 $\mathrm{NO}_{\mathrm{y}}$ and submicron scattering}

Analogous to Figs. 5 and 6, $\mathrm{NO}_{\mathrm{y}}$ (Fig. A2), and submicron scattering at $550 \mathrm{~nm}$ (Fig. A3) reconstructions are shown. The two component fit for total scattering yielded very similar results as the one for submicron scattering (e.g. fire fraction also equal to $57 \%$ ), with similar correlation coefficients. Significant amounts of aerosol nitrate were measured in and around Mexico City. For this analysis total $\mathrm{NO}_{\mathrm{y}}$ was taken as the sum of measured $\mathrm{NO}_{\mathrm{y}}$ and aerosol nitrate. While the $\mathrm{NO}_{\mathrm{y}}$ instrument likely measures some of the aerosol nitrate as $\mathrm{NO}_{\mathrm{y}}$, at this time it is not known what fraction of aerosol nitrate was sampled by the $\mathrm{NO}_{\mathrm{y}}$ instrument. To the extent aerosol nitrate is sampled by this $\mathrm{NO}_{\mathrm{y}}$ instrument, we are double counting the aerosol nitrate. The correlation with the 2-component model is significantly better if the aerosol nitrate is added to the $\mathrm{NO}_{\mathrm{y}}$ measurement to give total $\mathrm{NO}_{\mathrm{y}}$.

\section{A5 Altitude dependence of fire impact}

As observed from the C-130, and inferred by comparing the C-130 data with observations on the ground in Mexico City, the impact of the fires surrounding Mexico City is not as severe on the ground, as it is above the City. This is due in part to the location of the fires, elevated above the city on the mountainsides surrounding the city. The impact of fire 

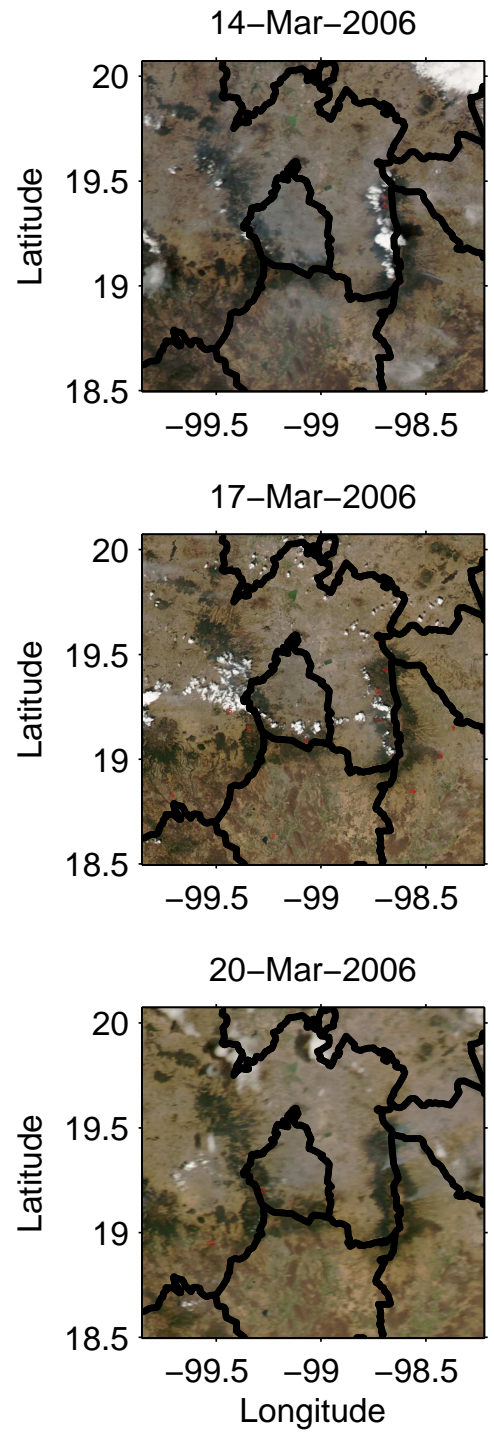
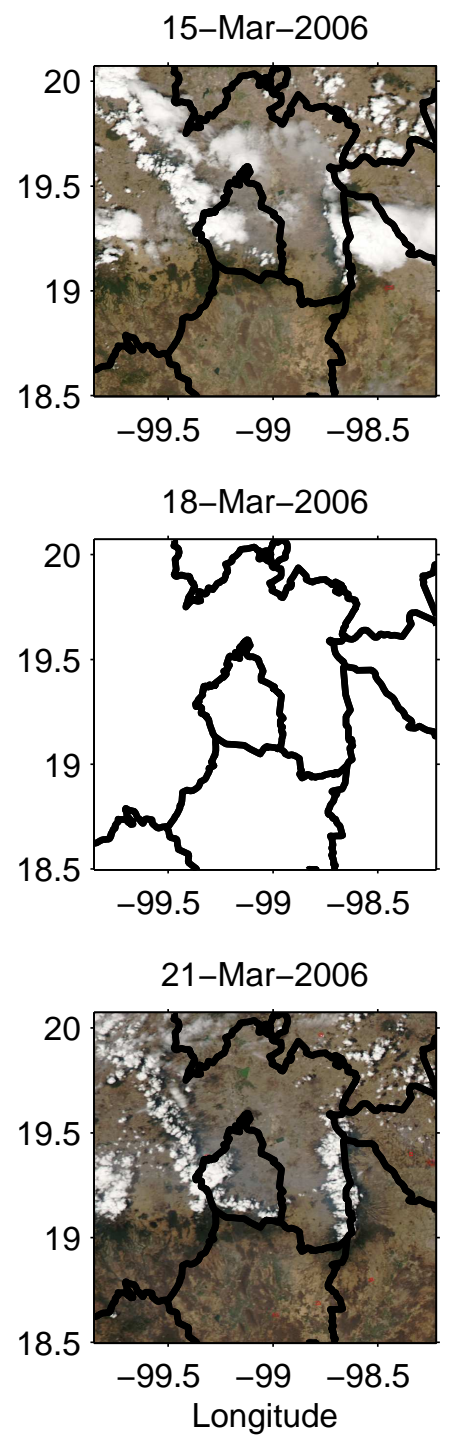
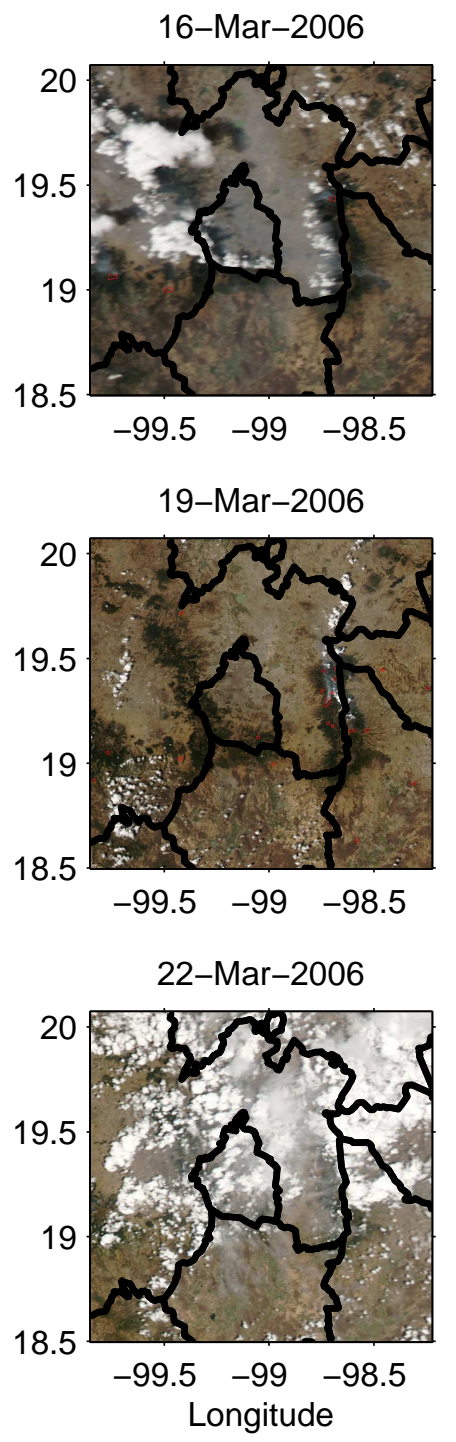

Fig. A6. MODIS-Aqua images around Mexico City for 14 March through 22 March 2006. Red boxes represent detected fires. Black lines are state boundaries. Blank areas represent missing data. Images courtesy of MODIS Rapid Response Project at NASA/GSFC.

increases with altitude above Mexico City (Fig. A4), suggesting that the smoke from the fires does not fully impact the ground.

\section{A6 Box size for study area}

The fire impact for the pollutants reported in the main text, considered a $3 \times 3$ degree rectangular study area, centered on Mexico City. As one decreases the box size, the urban emissions become relatively more important (Table A1). This makes sense considering the fires emissions originate from many diffuse sources (individual fires) scattered across the plateau, while the urban emissions are more centrally located in and around the MC basin. Table A1 compares the results for the 2-component model using three different box sizes.
Box 1 is the smallest, encompassing the populated area of Mexico City and some adjacent terrain. Box 2 is somewhat larger, including the ring of mountains around MC. Box 3 is the largest box, equating to the $3 \times 3$ degree box used for the results presented in the main body of this work.

\section{A7 MODIS Aqua satellite image time line}

A daily timeline of true color satellite images of the Mexico City area, collected from the MODIS instrument aboard the Aqua satellite, for the Month of March 2006 are shown in Figs. A5-A7. The images were taken at approximately 1:30 p.m. local time each day. The red boxes on each satellite image represent detected thermal anomalies. One can observe from inspection of the images that many fires 

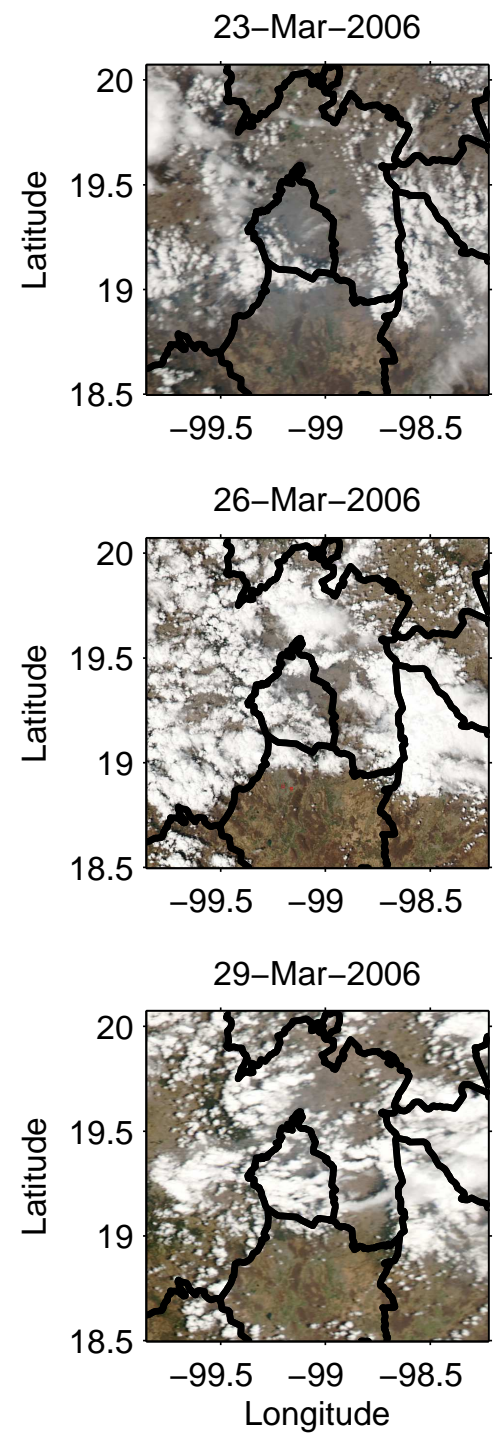
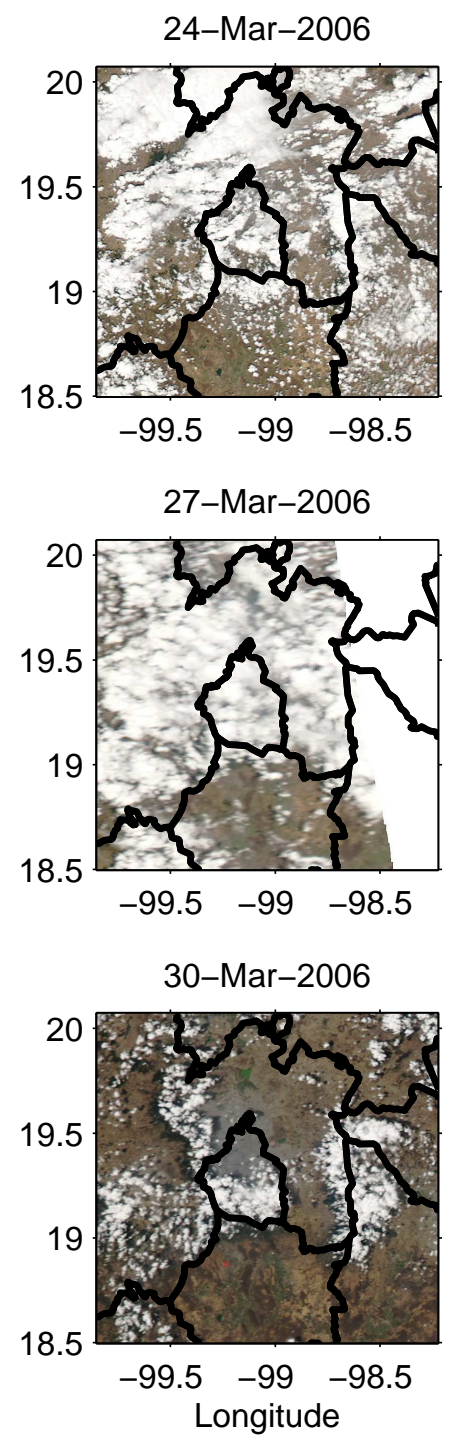
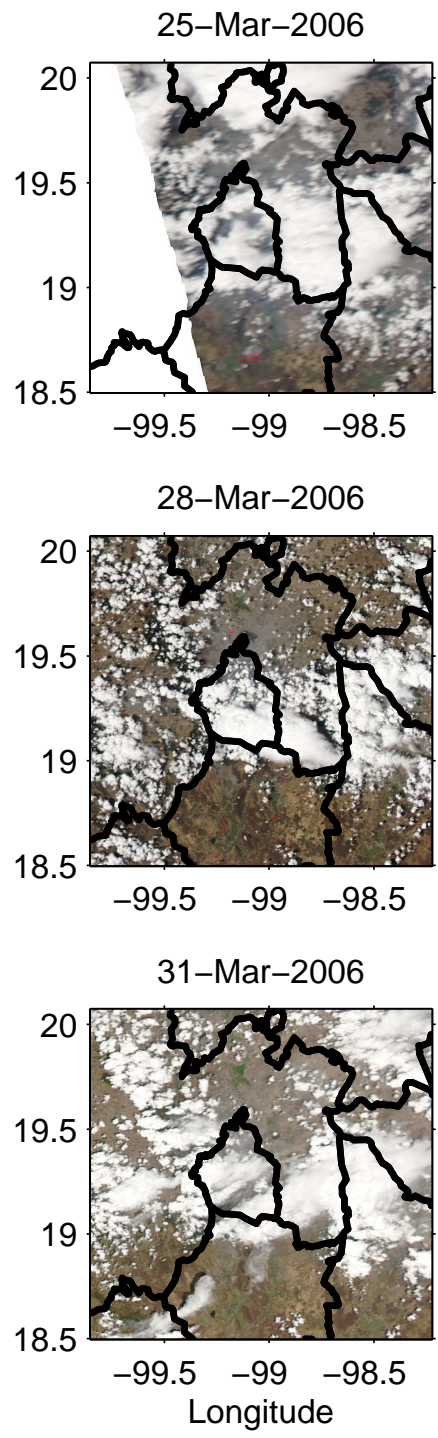

Fig. A7. MODIS-Aqua images around Mexico City for 23 March through 31 March 2006. Red boxes represent detected fires. Black lines are state boundaries. Blank areas represent missing data. Images courtesy of MODIS Rapid Response Project at NASA/GSFC.

are not detected due to a number of reasons, including cloud cover, smoke cover, low fire temperature, or simply lack of satellite coverage. Also, the number of detected fires does not necessarily correlate with the impact of fires on the visibility as observed from the satellite pictures. Higher resolution images are available as supplementary material (http://www.atmos-chem-phys.net/9/4929/ 2009/acp-9-4929-2009-supplement.pdf) for both Aqua and Terra images of the Mexico City region during March 2006.

Acknowledgements. The MIRAGE-mex campaign was a cooperative project of NASA and NSF. Funding for Caltech was provided through NASA (NAG: NNG06GB32B). We thank S. Madonich, F. Flocke, and NCAR's Research Aviation Facility (RAF) for mission design and support with instrument integration onto the aircraft. The National Center for Atmospheric Research is sponsored by the National Science Foundation. C. Wiedinmyer provided climatological fire data from the MODIS instrumentation. We thank J. Fast for comments on this work. We thank U. Steiner, J. Oliver, and N. Allen for technical support of the CIMS instruments whose development was generously supported by William and Sonja Davidow. J.D.C. and P.F.D. acknowledge support from the EPA-STAR Fellowship Program (FP916334012 and FP91650801). Funding for J.L.J. and P.D.F. was provided though NSF (ATM-0513116) and NASA grants (NNG06GB03G). D.R.B. acknowledges NSF's Atmospheric Chemistry Division (ACD) for support. This work has not been formally reviewed by the EPA. The views expressed in this document are solely those of the authors and the EPA does not endorse any products or commercial services mentioned in this publication. 
Edited by: S. Madronich

\section{References}

Aiken, A. C., Salcedo, D., Cubison, M. J., Huffman, J. A., DeCarlo, P. F., Ulbrich, I. M., Docherty, K. S., Sueper, D., Kimmel, J. R., Worsnop, D. R., Trimborn, A., Northway, M., Stone, E. A., Schauer, J. J., Volkamer, R., Fortner, E., de Foy, B., Wang, J., Laskin, A., Shutthanandan, V., Zheng, J., Zhang, R., Gaffney, J., Marley, N. A., Paredes-Miranda, G., Arnott, W. P., Molina, L. T., Sosa, G., and Jimenez, J. L.: Mexico City aerosol analysis during MILAGRO using high resolution aerosol mass spectrometry at the urban supersite (T0) - Part 1: Fine particle composition and organic source apportionment, Atmos. Chem. Phys. Discuss., 9, 8377-8427, 2009,

http://www.atmos-chem-phys-discuss.net/9/8377/2009/.

Anderson, T., Masonis, S., Covert, D., Ahlquist, N., Howell, S., Clarke, A., and McNaughton, C.: Variability of aerosol optical properties derived from in situ aircraft measurements during ACE-Asia, J. Geophys. Res.-Atmos., 108, 8647, doi:10.1029/ 2002JD003247, 2003.

Andreae, M. and Merlet, P.: Emission of trace gases and aerosols from biomass burning, Global Biogeochem. Cycles, 15, 955966, 2001.

Apel, E., Hills, A., Lueb, R., Zindel, S., Eisele, S., and Riemer, D.: A fast-GC/MS system to measure C-2 to C-4 carbonyls and methanol aboard aircraft, J. Geophys. Res.-Atmos., 108, 8794, doi:10.1029/2002JD003199, 2003.

Baum, M. M., Moss, J. A., Pastel, S. H., and Poskrebyshev, G. A.: Hydrogen cyanide exhaust emissions from in-use motor vehicles, Environ. Sci. Technol., 41, 857-862, doi:10.1021/es061402v, 2007.

Blake, N., Blake, D., Chen, T., Collins, J., Sachse, G., Anderson, B., and Rowland, F.: Distribution and seasonality of selected hydrocarbons and halocarbons over the western Pacific basin during PEM-West A and PEM-West B, J. Geophys. Res.-Atmos., 102, 28315-28331, 1997.

Bravo, A., Sosa, E., Sanchez, A., Jaimes, P., and Saavedra, R.: Impact of wildfires on the air quality of Mexico City, 1992-1999, Environ. Pollut., 117, 243-253, 2002.

Crounse, J. D., McKinney, K. A., Kwan, A. J., and Wennberg, P. O.: Measurement of gas-phase hydroperoxides by chemical ionization mass spectrometry, Anal. Chem., 78, 6726-6732, doi: 10.1021/ac0604235, 2006.

Cubison, M. J., Alfarra, M. R., Allan, J., Bower, K. N., Coe, H., McFiggans, G. B., Whitehead, J. D., Williams, P. I., Zhang, Q., Jimenez, J. L., Hopkins, J., and Lee, J.: The characterisation of pollution aerosol in a changing photochemical environment, Atmos. Chem. Phys., 6, 5573-5588, 2006, http://www.atmos-chem-phys.net/6/5573/2006/.

de Gouw, J., Middlebrook, A., Warneke, C., Goldan, P., Kuster, W., Roberts, J., Fehsenfeld, F., Worsnop, D., Canagaratna, M., Pszenny, A., Keene, W., Marchewka, M., Bertman, S., and Bates, T.: Budget of organic carbon in a polluted atmosphere: Results from the New England Air Quality Study in 2002, J. Geophys. Res.-Atmos., 110, d16305, doi:10.1029/2004JD005623, 2005.

de Gouw, J. A., Welsh-Bon, D., Warneke, C., Kuster, W. C., Alexander, L., Baker, A. K., Beyersdorf, A. J., Blake, D. R., Canagaratna, M., Celada, A. T., Huey, L. G., Junkermann, W., Onasch,
T. B., Salcido, A., Sjostedt, S. J., Sullivan, A. P., Tanner, D. J., Vargas, O., Weber, R. J., Worsnop, D. R., Yu, X. Y., and Zaveri, R.: Emission and chemistry of organic carbon in the gas and aerosol phase at a sub-urban site near Mexico City in March 2006 during the MILAGRO study, Atmos. Chem. Phys., 9, 3425-3442, 2009,

http://www.atmos-chem-phys.net/9/3425/2009/.

DeCarlo, P. F., Kimmel, J. R., Trimborn, A., Northway, M. J., Jayne, J. T., Aiken, A. C., Gonin, M., Fuhrer, K., Horvath, T., Docherty, K. S., Worsnop, D. R., and Jimenez, J. L.: Field-deployable, high-resolution, time-of-flight aerosol mass spectrometer, Anal. Chem., 78, 8281-8289, doi:10.1021/ac061249n, 2006.

DeCarlo, P. F., Dunlea, E. J., Kimmel, J. R., Aiken, A. C., Sueper, D., Crounse, J., Wennberg, P. O., Emmons, L., Shinozuka, Y., Clarke, A., Zhou, J., Tomlinson, J., Collins, D. R., Knapp, D., Weinheimer, A. J., Montzka, D. D., Campos, T., and Jimenez, J. L.: Fast airborne aerosol size and chemistry measurements above Mexico City and Central Mexico during the MILAGRO campaign, Atmos. Chem. Phys., 8, 4027-4048, 2008, http://www.atmos-chem-phys.net/8/4027/2008/.

Efron, B. and Tibshirani, R.: An Introduction to the Bootstrap, Monographs on Statistics and Applied Probability, 57, 1-177, 1993.

Fast, J. D., de Foy, B., Acevedo Rosas, F., Caetano, E., Carmichael, G., Emmons, L., McKenna, D., Mena, M., Skamarock, W., Tie, X., Coulter, R. L., Barnard, J. C., Wiedinmyer, C., and Madronich, S.: A meteorological overview of the MILAGRO field campaigns, Atmos. Chem. Phys., 7, 2233-2257, 2007, http://www.atmos-chem-phys.net/7/2233/2007/.

Fast, J. D., Aiken, A. C., Allan, J., Alexander, L., Campos, T., Canagaratna, M. R., Chapman, E., DeCarlo, P. F., de Foy, B., Gaffney, J., de Gouw, J., Doran, J. C., Emmons, L., Hodzic, A., Herndon, S. C., Huey, G., Jayne, J. T., Jimenez, J. L., Kleinman, L., Kuster, W., Marley, N., Russell, L., Ochoa, C., Onasch, T. B., Pekour, M., Song, C., Ulbrich, I. M., Warneke, C., WelshBon, D., Wiedinmyer, C., Worsnop, D. R., Yu, X.-Y., and Zaveri, R.: Evaluating simulated primary anthropogenic and biomass burning organic aerosols during MILAGRO: implications for assessing treatments of secondary organic aerosols, Atmos. Chem. Phys. Discuss., 9, 4805-4871, 2009, http://www.atmos-chem-phys-discuss.net/9/4805/2009/.

Gerbig, C., Schmitgen, S., Kley, D., Volz-Thomas, A., Dewey, K., and Haaks, D.: An improved fast-response vacuum-UV resonance fluorescence CO instrument, J. Geophys. Res.-Atmos., 104, 1699-1704, 1999.

Giglio, L., Descloitres, J., Justice, C., and Kaufman, Y.: An enhanced contextual fire detection algorithm for MODIS, Rem. Sens. Environ., 87, 273-282, doi:10.1016/S0034-4257(03) 00184-6, 2003.

Grosjean, E., Grosjean, D., and Rasmussen, R.: Ambient concentrations, sources, emission rates, and photochemical reactivity of C-2-C-10 hydrocarbons in Porto Alegre, Brazil, Environ. Sci. Technol., 32, 2061-2069, 1998.

Harvey, C., Garbe, R., Baines, T., Somers, J., Hellman, K., and Carey, P.: A study of the potential impact of some unregulated motor vehicle emissions, SAE Transactions, 92, 3-3, 1983.

Horowitz, L., Walters, S., Mauzerall, D., Emmons, L., Rasch, P., Granier, C., Tie, X., Lamarque, J., Schultz, M., Tyndall, G., Orlando, J., and Brasseur, G.: A global simulation of tropo- 
spheric ozone and related tracers: Description and evaluation of MOZART, version 2, J. Geophys. Res.-Atmos., 108, 4784, doi: 10.1029/2002JD002853, 2003.

Kleinman, L. I., Springston, S. R., Daum, P. H., Lee, Y.-N., Nunnermacker, L. J., Senum, G. I., Wang, J., Weinstein-Lloyd, J., Alexander, M. L., Hubbe, J., Ortega, J., Canagaratna, M. R., and Jayne, J.: The time evolution of aerosol composition over the Mexico City plateau, Atmos. Chem. Phys., 8, 1559-1575, 2008, http://www.atmos-chem-phys.net/8/1559/2008/.

Kroll, J. H. and Seinfeld, J. H.: Chemistry of secondary organic aerosol: Formation and evolution of low-volatility organics in the atmosphere, Atmos. Environ., 42, 3593-3624, doi:10.1016/j. atmosenv.2008.01.003, 2008.

Leppalahti, J. and Koljonen, T.: Nitrogen evolution from coal, peat and wood during gasification - Literature-review, Fuel Process. Technol., 43, 1-45, 1995.

Li, Q., Jacob, D., Yantosca, R., Heald, C., Singh, H., Koike, M., Zhao, Y., Sachse, G., and Streets, D.: A global three-dimensional model analysis of the atmospheric budgets of $\mathrm{HCN}$ and $\mathrm{CH} 3 \mathrm{CN}$ : Constraints from aircraft and ground measurements, J. Geophys. Res.-Atmos., 108, 8827, doi:10.1029/2002JD003075, 2003.

Lloyd, A.: California clean-air initiatives - The role of fuel cells, J. Power Sources, 37, 241-253, 1992.

McKinley, G., Zuk, M., Hojer, M., Avalos, M., Gonzalez, I., Iniestra, R., Laguna, I., Martinez, M., Osnaya, P., Reynales, L., Valdes, R., and Martinez, J.: Quantification of local and global benefits from air pollution control in Mexico City, Environ. Sci. Technol., 39, 1954-1961, doi:10.1021/es035183e, 2005.

Moffet, R. C., de Foy, B., Molina, L. T., Molina, M. J., and Prather, K. A.: Measurement of ambient aerosols in northern Mexico City by single particle mass spectrometry, Atmos. Chem. Phys., 8, 4499-4516, 2008, http://www.atmos-chem-phys.net/8/4499/2008/.

Molina, L. and Molina, M.: Air Quality in the Mexico Megacity: An Integrated Assessment, Kluwer Academic Publishers, 2002.

Molina, L. T., Kolb, C. E., de Foy, B., Lamb, B. K., Brune, W. H., Jimenez, J. L., Ramos-Villegas, R., Sarmiento, J., ParamoFigueroa, V. H., Cardenas, B., Gutierrez-Avedoy, V., and Molina, M. J.: Air quality in North America's most populous city overview of the MCMA-2003 campaign, Atmos. Chem. Phys., 7, 2447-2473, 2007, http://www.atmos-chem-phys.net/7/2447/2007/.

Muhle, J., Lueker, T. J., Su, Y., Miller, B. R., Prather, K. A., and Weiss, R. F.: Trace gas and particulate emissions from the 2003 southern California wildfires, J. Geophys. Res.-Atmos., 112, d03307, doi:10.1029/2006JD007350, 2007.

NEI: Mexico National Emissions Inventory, 1999, http://www. epa.gov/ttn/chief/net/mexico/1999_mexico_nei_final_report.pdf, 2008.

Ratcliff, M., Medley, E., and Simmonds, P.: Pyrolysis of aminoacids - Mechanistic considerations, J. Org. Chem., 39, 14811490, 1974.

Robinson, A. L., Donahue, N. M., Shrivastava, M. K., Weitkamp, E. A., Sage, A. M., Grieshop, A. P., Lane, T. E., Pierce, J. R., and Pandis, S. N.: Rethinking organic aerosols: Semivolatile emissions and photochemical aging, Science, 315, 1259-1262, doi:10.1126/science.1133061, 2007.

Salcedo, D., Onasch, T. B., Dzepina, K., Canagaratna, M. R., Zhang, Q., Huffman, J. A., DeCarlo, P. F., Jayne, J. T., Mor- timer, P., Worsnop, D. R., Kolb, C. E., Johnson, K. S., Zuberi, B., Marr, L. C., Volkamer, R., Molina, L. T., Molina, M. J., Cardenas, B., Bernab, R. M., Márquez, C., Gaffney, J. S., Marley, N. A., Laskin, A., Shutthanandan, V., Xie, Y., Brune, W., Lesher, R., Shirley, T., and Jimenez, J. L.: Characterization of ambient aerosols in Mexico City during the MCMA-2003 campaign with Aerosol Mass Spectrometry: results from the CENICA Supersite, Atmos. Chem. Phys., 6, 925-946, 2006,

http://www.atmos-chem-phys.net/6/925/2006/.

Sigsby, J., Tejada, S., Ray, W., Lang, J., and Duncan, J.: Volitile organic-compound emissions from 46 in-use passenger cars, Environ. Sci. Technol., 21, 466-475, 1987.

Singh, H., Salas, L., Herlth, D., Kolyer, R., Czech, E., Viezee, W., Li, Q., Jacob, D., Blake, D., Sachse, G., Harward, C., Fuelberg, H., Kiley, C., Zhao, Y., and Kondo, Y.: In situ measurements of $\mathrm{HCN}$ and $\mathrm{CH} 3 \mathrm{CN}$ over the Pacific Ocean: Sources, sinks, and budgets, J. Geophys. Res.-Atmos., 108, 8795, doi: 10.1029/2002JD003006, 2003.

Solomon, S., Qin, D., Manning, M., Chen, Z., Marquis, M., Averyt, K., Tignor, M., and Miller, H.: IPCC, 2007: Climate Change 2007: The Physical Science Basis. Contribution of Working Group I to the Fourth Assessment Report of the Intergovernmental Panel on Climate Change, 2007.

Stone, E. A., Snyder, D. C., Sheesley, R. J., Sullivan, A. P., Weber, R. J., and Schauer, J. J.: Source apportionment of fine organic aerosol in Mexico City during the MILAGRO experiment 2006, Atmos. Chem. Phys., 8, 1249-1259, 2008,

http://www.atmos-chem-phys.net/8/1249/2008/.

Volkamer, R., Jimenez, J. L., San Martini, F., Dzepina, K., Zhang, Q., Salcedo, D., Molina, L. T., Worsnop, D. R., and Molina, M. J.: Secondary organic aerosol formation from anthropogenic air pollution: Rapid and higher than expected, Geophys. Res. Lett., 33, 117811, doi:10.1029/2006GL026899, 2006.

Weber, R. J., Sullivan, A. P., Peltier, R. E., Russell, A., Yan, B., Zheng, M., de Gouw, J., Warneke, C., Brock, C., Holloway, J. S., Atlas, E. L., and Edgerton, E.: A study of secondary organic aerosol formation in the anthropogenic-influenced southeastern United States, J. Geophys. Res.-Atmos., 112, d13302, doi:10. 1029/2007JD008408, 2007.

WHO: Air Quality and Health, http://www.who.int/mediacentre/ factsheets/fs313/en/index.html, 2008.

Xiao, Y., Jacob, D. J., and Turquety, S.: Atmospheric acetylene and its relationship with $\mathrm{CO}$ as an indicator of air mass age, J. Geophys. Res.-Atmos., 112, d12305, doi:10.1029/2006JD008268, 2007.

Yokelson, R. J., Karl, T., Artaxo, P., Blake, D. R., Christian, T. J., Griffith, D. W. T., Guenther, A., and Hao, W. M.: The Tropical Forest and Fire Emissions Experiment: overview and airborne fire emission factor measurements, Atmos. Chem. Phys., 7, 5175-5196, 2007a, http://www.atmos-chem-phys.net/7/5175/2007/.

Yokelson, R. J., Urbanski, S. P., Atlas, E. L., Toohey, D. W., Alvarado, E. C., Crounse, J. D., Wennberg, P. O., Fisher, M. E., Wold, C. E., Campos, T. L., Adachi, K., Buseck, P. R., and Hao, W. M.: Emissions from forest fires near Mexico City, Atmos. Chem. Phys., 7, 5569-5584, 2007b, http://www.atmos-chem-phys.net/7/5569/2007/. 